БАБАЯН ДАВИД

\title{
ФОРМИРОВАНИЕ АЗЕРБАЙДЖАНСКОГО НАРОДА (ОТ ТАТАРИЗАЦИИ ДО АЗЕРБАЙДЖАНИЗАЦИИ) В КОНТЕКСТЕ АДМИНИСТРАТИВНО-ТЕРРИТОРИАЛЬНОЙ И ЭТНОНАЦИОНАЛЬНОЙ ГЕОПОЛИТИКИ В ЗАКАВКАЗЬЕ B XIX-XX BB.
}

Ключевые слова: татаризация, татары, азербайджанизация, Закавказье, Армянская область, Армения, Арцах, Грузия, Персия, Россия.

\section{Присоединение Закавказья к Российской империи}

После присоединения Закавказья Российская империя получила стратегически важнейший регион, контроль над которым существенно повышал уровень безопасности страны и давал возможность решать целый ряд стратегически важнейших геополитических задач на Ближнем и Среднем Востоке.

Еще до присоединения Закавказья российские правящие круги разрабатывали проекты политического устройства данного края. Вначале были планы создания в регионе христианских государств под покровительством Российской империи. Грузинские государства, как уже отмечалось ранее, тогда существовали, и после подписания в 1783 году Георгиевского трактата, объединенное Картлийско-Кахетинское грузинское царство стало протекторатом России. Примечательно, что в грузинском тексте трактата был представлен более полный титул грузинского царя, где он титулуется как «наследственный государь и владетель Ираклий Второй, Божьей милостыю и благоволением Его Императорского Величества царь Карталинский, царь Кахетинский, наслед- 
ственный владетель Самцхе-Саатабагский, владетельный князь Казахский, Борчалинский, Шамшадильский, Какский, Шакийский, Ширванский, владетель и повелитель Ганджи и Эривани» ${ }^{.}$Фактически, получалось, что заключив Георгиевский трактат, Россия теоретически заявляла свои права на большую часть Закавказья.

В 1780-х годах царское правительство рассматривало вопрос создания под своим протекторатом и армянского государства ${ }^{2}$. То, что Грузия стала протекторатом России великой христианской державы, сохранив свое внутреннее самоуправление, было весьма привлекательным сценарием и для армян, которые с великим воодушевлением отнеслись к этому событию. Ядром воссозданного армянского государства должен был стать Карабах. В одном из директив из Петербурга в регион было указано следующее: "...Карабаг составит армянскую независимую, кроме России, никому область» ${ }^{3}$. Такие планы, естественно, вызывали сильнейший резонанс в среде армянства, причем не только Персии, но и Османской империи. Не случайно, что армяне принимали самое действенное участие в войне между Россией и Персией, всемерно помогая русским войскам и участвуя практически во всех важнейших сражениях, что особенно наглядно проявилось в Карабахе $\left(\right.$ Арцахе) ${ }^{4}$. Кроме того, армяне зани-

\footnotetext{
${ }^{1}$ Авалов 3.Д.. Присоединение Грузии к России. Санкт-Петербург, 1906, стр. 54-55.

2 РГВИА (Российский Государственный Военно-Исторический Архив), дел. 25, лл. 9-12; Иоаннисян А. Россия и армянское освободительное движение в 80-х годах XVIII столетия. Ереван, 1947, стр. 190-191.

3 Маркова О.П. Россия, Закавказье и международные отношения в XVIII веке. Москва, 1966, стр. 161.

${ }^{4}$ См., в частности, Потто В. Первые добровольцы Карабага в эпоху водворения русского владычества. Тифлис, 1902, стр. 24, 58.
} 
мали и весьма важное значение в экономике Ближнего Востока.

Но самым интересным проектом было намерение воссоздать Албанию Кавказскую. В одном из правительственных документов указывалось следующее: «Чтоб и о тех землях, кои назначаются к составлению области или царства Албанского, сделано было ясное постановление» 5 . Однако, воссоздать Албанию Кавказскую, естественно, было уже невозможно и данный проект так и остался на бумаге.

Между 1804 и 1813 гг. Российская империя взяла под свой контроль большую часть Закавказья, за исключением Ереванского и Нахичеванского ханств, что было закреплено Гюлистанским договором 1813 года.

Закавказье в составе Российской империи. Административно-территориальная эволючия региона

Практически сразу после инкорпорации Закавказья Российская империя стала проводить здесь административно-территориальную реформу и преобразования. Одним из самых первых стало преобразование в 1801 году КартлиКахетинского царства в Грузинскую губернию. Это преобразование было не только административным, но и политическим. Грузия становилась составной частью России и сохранение независимого грузинского государства, даже под протекторатом русского государства, уже выводилось из геополитической повестки Российской империи. Инкорпорация Грузии была всеобъемлющей и не ограничилась лишь политико-административной сферой. В 1811 году Грузинская православная церковь потеряла свою автокефалию или са-

${ }^{5}$ Центральный государственный исторический архив (ЦГИА), ф. 52, оп. 2/203, д. 37, лл. 63-64; РГВИА, оп.1\194. д.331, ч.4, л. 40. 
мостоятельность, став Грузинским экзархатом Русской православной церкви, ${ }^{6}$ просуществовавшим до 1917 года.

Но в то же самое время, с созданием Грузинской губернии, в политический и административный обиход деюре снова вошло название «Грузия», пусть даже в качестве губернии. Вместо раздробленных на несколько частей, зачастую враждовавших друг с другом и имеющих различные названия исторических областей Грузии, создавалось нечто единое. Также создавались предпосылки освобождения остальных исторических грузинских территорий, в первую очередь Имеретинского царства, находившегося в вассальной зависимости от Османской империи и постоянно подвергавшегося вторжению и разорению со стороны османов. В 1804 году Имеретинское царство приняло покровительство Российской империи, а в 1811 году оно было преобразовано в Имеретинскую область ${ }^{7}$. Отдельной административной единицей было Мегрельское княжество, упраздненное лишь в 1867 году. Но вот единого грузинского административно-территориального образования со всеми основными политико-историческими единицами (Картли, Кахетия, Имеретия и т.д.) тогда создано не было. С точки зрения имперских интересов это было объективно и логично. Создавать на пограничных пространствах единое национальное административно-территориальное образование было достаточно рискованно, тем более в случае Грузии, которая

\footnotetext{
${ }^{6}$ Подробнее о данной теме см., в частности, Православная богословская энциклопедия, Санкт-Петербург, 1902, т. IV, стр. 717-750.

7 О данном преобразовании см., в частности, Полное собрание законов Российской империи с 1649 года. Собрание первое. Том XXXI. 1810-1811, Санкт-Петербург, 1830, стр. 615-618.
} 
часто проявляла геополитическую “строптивость” и отличалась своим свободолюбием.

Кроме того, было важно и то, чтобы эти национальнотерриториальные образования были многонациональными, причем без заметного преобладания какой-либо нации или народности в пределах данного субъекта. Это давало возможность уменьшить возможные консолидированные попытки сецессии, особенно против единоверной метрополии. Грузия, в частности Картли-Кахетинское царство, была традиционно многонациональным государством. В 1806 году в состав Грузинской губернии было включено Гянджинское ханство, которое стало Елисаветпольским округом, а затем и уездом данной губернии ${ }^{8}$. Такое решение с одной стороны удовлетворяло политико-исторические амбиции грузинской общественности, с другой стороны делало население данной губернии еще более пестрым в этно-религиозном отношении. В середине 1830-х годов основное население Грузинской губернии в этническом отношении было следующим: различные этнические группы грузин (тогда в качестве отдельных народностей наряду с собственно грузинами были представлены различные группы грузин, в частности, тушинцы, пшавы, имеретинцы, мегрелы и т.д.) - 132,5 тыс., армян - 144 тыс., татар - 77,5 тыс., осетин - 20 тыс. человек ${ }^{9}$. Жили здесь также греки, немцы, евреи, русские и другие национальности. Население же губернского центра -

\footnotetext{
8 Подробнее о данном уезде см. в частности, Географическо-статистический словарь Российской империи. Т. II, Санкт-Петербург, 1865, стр. 188-190.

${ }^{9}$ Евецкий О. Статистическое описание Закавказского края с присовокуплением статьи: Политическое состояние Закавказского края в исходе XVIII века и сравнение онаго с нынешним. СПб., 1835, стр. 131.
} 
Тифрлиса, составляло тогда 25,2 тыс. человек, из коих 18,8 тыс. были армяне ${ }^{10}$.

Что касается других частей Закавказья, то здесь были применены аналогичные подходы с учетом местных особенностей. В 1805 году Шекинское, а годом позже Дербентское и Кубинское ханства стали частью России и в 1806 году были преобразованы в одноименные провинции. Некоторые единицы, вошедшие в состав Российской империи сохранили статус ханства подольше. Так, Ширванское и Карабахское ханства, став частью России в 1805 годы, были переименованы в провинции в 1820 и 1822 гг. соответственно, а Талышское ханство, которое было присоединено к Российской империи в 1813 году, стало одноименной провинцией в 1826 году. Вначале местные правители были назначены управляющими данными ханствами или провинциями, хотя их правление уже носило номинальный характер, затем власть перешла в руки имперских властей ${ }^{11}$.

В 1828 году в состав Российской империи вошли Эриванское и Нахичеванское ханства, объединением которых в том же году была образована Армянская область ${ }^{12}$. Образование Армянской области было поистине историческим событием для армянского народа и достаточно интересным геополитическим шагом. После падения последнего независимого армянского царства в XIV веке, название "Армения» было лишь историческим и географическим понятием. Впервые за 500 лет название «Армения» снова приобрела

\footnotetext{
${ }^{10}$ Евецкий О. Указ. соч., стр. 142.

${ }^{11}$ См., например, Мирза Джамал Джеваншир Карабагский. История Карабага. Баку, 1959, стр. 98.

12 О указе см., в частности, Акты, собранные Кавказской археографической комиссией. Т. VII, Тифлис, 1878, стр. 487.
} 
административно-политический контур.

Существование грузинской и армянской административно-политических единиц в пределах Российской империи, непосредственно граничащих с Османской империей, было весьма действенным геополитическим шагом не только в контексте оказания влияния на проживающих в пределах Турции этнических армян и грузин, но и в плоскости взаимоотношений с другими христианскими нацменьшинствами Порты. По некоторым данным, в середине XIX века в Османской империи проживали 7 млн. человек, принадлежащих к различным славянским народам, 4 млн. представителей романских народов, 2,5 млн. армян, 2 млн. греков, 1,5 млн. албанцев ${ }^{13}$. Естественно, что это была сила, которая могла сыграть важную роль в геополитике Восточной Европы и Ближнего Востока, особенно, если учитывать, что большая часть христианских народов видела в России освободительницу.

Армянская область также была многонациональным и многоконфессиональным образованием. Здесь жили армяне, татары, персы, курды, езиды, цыгане, русские, ассирийцы и другие народы. Численность армян составляла 82,3 тыс. человек, а всех мусульманских народов вместе взятых - 81,7 тыс. человек ${ }^{14}$. Но в состав Армянской области не вошли ряд исторических армянских территорий, в частности, Карабах, который, как уже отмечалось выше, ранее рассматривался в качестве ядра будущего армянского госу-

${ }^{13}$ Creasy Edward S., History of the Ottoman Turks. From the Beginning of their Empire to the Present Time, New York, 1878, p. 7.

${ }^{14}$ Шопен И. Исторический памятник состояния Армянской области в эпоху присоединения ее к Российской империи. Санкт-Петербург, 1852, стр. 654, 663. 
дарства. Расчеты здесь, как и в случае с Грузией, были подчинены логике и императивам общеимперской административно-территориальной политике, где одним из ключевых компонентов являлось нецелесообразность создания моноэтнических административно-территориальных единиц в национальных регионах империи, особенно в среде народов, у которых была достаточно длинная история независимой государственности.

Что касается Восточного Закавказья, то там не были образованы национальные губернии. Как уже отмечалось, были планы воссоздать Албанию Кавказскую, но в XIX веке это, естественно, было невозможно по той простой причине, что коренным образом изменился этнополитический ландшафрт региона. Он стал мозаикой и конгломератом разных народов, племен и религиозных групп. Здесь также не сорормировался и новый единый народ.

Однако уже в 1830-х годах имперская политика начала претерпевать определенные изменения и начался этап постепенного упразднения национальных административных единиц и их трансорормацию в территориальные. Надо отметить, что такие прецеденты в истории Российский империи были. Так, в 1796 году была образована Белорусская губерния с центом в Витебске, которая была упразднена в 1802 году и на ее месте были образованы Витебская и Могилевская губернии. В том же 1796 году была образована и Малороссийская губерния с центром в Чернигове. В 1802 году эта губерния также была упразднена и на ее месте были образованы Черниговская и Полтавская губернии ${ }^{15}$. В

\footnotetext{
15 Об упразднении Белорусской и Малороссийской губерний. См. Полное собрание законов Российской империи с 1649 года. Собрание первое. Том XXVII. 1802-1803, Санкт-Петербург, 1830, стр. 59-60.
} 
1796 году была образована и Литовская губерния, которая была упразднена указами 1801 и 1802гг. с образованием на ее месте Виленской и Гродненской губерний ${ }^{16}$. Кроме того, в июле 1840 года вышло высочайшее повеление, в соответствии с которым отныне запрещалось использовать названия Белорусские и Литовские губернии, вместо которых надлежало использовать названия Витебская, Могилевская и Виленская, Гродненская губернии соответственно ${ }^{17}$.

Похожая ситуация была и в случае Польши. В январе 1897 года император Николай II распорядился, не устраняя из Свода Законов наименования Царство Польское и губернии Царства Польского, ограничить их употребление случаями крайней необходимости ${ }^{18}$. Вместо этого все чаще употреблялись названия «губернии Привислинского края», «Привислинские губернии» и «Привислинский край». Именно под названием «Привислинский край» указана территория российской Польши, например, в атласе Российское империи по губерниям и областям с географическими картами 1913 года издания ${ }^{19}$. Кстати, Польское восстание 183031гг. лишний раз показало важность создания губерний с разнородным этноконфрессиональным составом.

\footnotetext{
16 Полное собрание законов Российской империи с 1649 года. Собрание первое. Том XXVI, 1800-1801, Санкт-Петербург, 1830, стр. 779-780.

17 Полное собрание законов Российской империи. Собрание второе. Том XV, отделение первое, 1840, Санкт-Петербург, 1841, стр. 515.

18 Бахтурина А.Ю., Государственное управление западными окраинами Российской империи, (1905 - февраль 1917г.), диссертация доктора ист. наук, Москва, 2006, стр. 22.

${ }^{19}$ См. Соответствующий раздел атласа Россія. Географическое описаніе Россійское Имперіи по губерніямъ и областямъ съ географическими картами. Санкт-Петербург, 1913, стр. 111-131.
} 
В Закавказье дальнейший ход административно-территориальных преобразований шел в несколько этапов. Первым стало дальнейшее укрупнение административных единиц, с обязательным сохранением полиэтничности и многоконфессиональности. 10 апреля 1840 года вышло достаточно объемное постановление императора Николая I под названием «Учреждение для управления Закавказским краем», в соответствии с которым Имеретинская, Грузинская губернии и Армянская область объединялись в единую административно-территориальную единицу - ГрузиноИмеретинскую губернию с центром в Тифрлисе, а все провинции Восточного Закавказья объединялись в одну единицу - Каспийскую область с центром в Шемахе ${ }^{20}$.

Объединение провинций Восточного Закавказья в единую административно-территориальную единицу позволяло одновременно решить ряд важных геополитических задач. Границы провинций были идентичными их границам времен полунезависимых ханств, а бывшее правящее сословие сохраняло немало привилегий. Сохранив прежние границы, лишь переименовав ханства в провинции, было не слишком дальновидным и политически целесообразным решением, которое при подходящих условиях было чревато сепаратизмом, особенно, учитывая географическое положение региона и непрекращающуюся геополитическую конкуренцию за этот регион.

Особую важность здесь приобретало новое административно-территориальное устройство, подразумевающее создание новых субъектов, которые были выше по своему статусу, чем существующие провинции или бывшие хан-

\footnotetext{
${ }^{20}$ Полное собрание законов Российской империи. Собрание второе. Том XV, отделение первое, 1840, Санкт-Петербург, 1841, стр. 237-265.
} 
ства. Последние должны были войти в их состав в качестве более мелкой единицы. При этом, границы бывших административно-территориальных единиц также подвергались изменениям.

Итак, в 1840 году, как уже отмечалось выше, была образована Каспийская область. В состав области вошли семь уездов: Ширванский, Карабахский, Шекинский, Талышинский, Бакинский, выделенные в особый военный округ Дербентский и Кубинский уезды ${ }^{21}$.

Данное административно-территориальное устройство было своего рода переходным этапом от национальной основы территориального деления к административной. В названии Грузино-имеретинская губернии прослеживался определенный национальный корень. Это естественно, Грузия и Имеретия в качестве стран, и грузины с имеретинцами в качестве народов. Однако, назвать эту губернию грузинской было сложно. Во-первых, национальный состав был очень пестрым, в во-вторых, из названия уже было видно, что Грузия и Имеретия разные территории, а имеретинцы, будучи этнической группой грузин, все-таки не совсем грузины. Название же уездов этой губернии уже имели чисто административный корень. Что касается Каспийской области, то здесь имелась своя специфика. Название области имело чисто географический корень, без каких-либо этнополитических мотивов. Но с другой стороны, в названии ряда уездов еще сохранялся этнополитический оттенок. Так, название Талишинский уезд ясно указывал на этническую принадлежность данной территории к талышскому народу, Карабахский и Ширванский уезды содержали в себе элемен-

${ }^{21}$ Полное собрание законов Российской империи. Собрание второе. Том XV, отделение первое, 1840, указ. док., стр. 237. 
ты государственности, особенно учитывая роль и влияние этих образований в период ханств.

В 1846 году была проведена очередная административно-территориальная реформа Закавказья. Грузино-имеретинская губерния была разделена на две губернии - Тифрлисскую и Кутаисскую, с губернскими центрами в Тифлисе и Кутаисе соответственно, а на месте Каспийской области образовывались Шемахинская и Дербентская губернии с губернскими центрами в Шемахе и Дербенте соответственно $^{22}$. Кроме того, были переименованы и уезды Шемахинской губернии. Ширванский уезд был переименован в Шемахинский, Карабахский - в Шушинский, Шекинский - в Нухинский, Талышинский - в Ленкоранский ${ }^{23}$. Таким образом, был осуществлен переход от этнополитической основы административно-территориального деления к сугубо территориальной, где название губерний и уездов были производными от губернских и уездных центров. Что касается Дербентской губернии, известной также как Прикаспийский край, то она была образована из Дербентского и Кубинского уездов и других территорий Дагестана. В 1847 году Дербентская губерния, шамхальство Тарковское и Мехтулинское ханство составили новую административную единицу - Прикаспийский край с центром в Дербенте ${ }^{24}$. Это, пожалуй, был единственный период в истории Дагестана, когда большин-

22 Подробнее о данном постановлении см. Полное собрание законов Российской империи. Собрание второе. Том XXI, отделение первое, 1846, СанктПетербург, 1847, стр. 647-656.

${ }^{23}$ Полное собрание законов Российской империи. Собрание второе. Том XXI, отделение первое, 1846, указ. док., стр. 647.

24 «Документы по истории Дагестана XIX в.», Вопросы истории Дагестана (досоветский период). Вып. 2. Махачкала, 1975, стр. 255-256. 
ство его земель были включены в единую административно-территориальную единицу.

Но на этом административно-территориальная реформа края не была завершена. В 1849 году была образована Эриванская губерния с губернским центром в Эриване, в состав которой вошли Эриванский, Нахичеванский и Александропольский уезды (кроме участка Ахалкалахского) Тифрлисской губернии участок Мигринский и селение Капак Шушинского уезда Шемахинской губернии ${ }^{25}$. Эта губерния по своей территории практически соответствовала Армянской области, за исключением Александропольского уезда и ряда малых участков.

В 1859 году город Шемаха был разрушен землетрясением, в связи с чем в декабре того же года управление губернией и все находившиеся там губернские учреждения были переведены в Баку и губерния была переименована в Бакинскую ${ }^{26}$.

В июле 1860 года в соответствии с указом императора Александра II, в Закавказье произошли очередные административно-территориальные изменения. Был упразднен Прикаспийский край. Кубинский уезд был передан Бакинской губернии, а остальная ее часть вошла в состав новообразованной Дагестанской области ${ }^{27}$. В соответствии с тем же самым указом, на правах губернии был также образован Закатальский округ ${ }^{28}$.

25 Полное собрание законов Российской империи. Собрание второе. Том XXIV, отделение первое, 1849, Санкт-Петербург, 1850, стр. 311-312.

${ }^{26}$ Документы по истории Баку. 1810-1917, Баку, 1978, стр. 69.

27 Полное собрание законов Российской империи. Собрание второе. Том XXXV, отделение первое, 1860, Санкт-Петербург, 1862, стр. 917.

28 Там же. 
В 1866 году был образован Сухумский военный отдел Кавказского наместничества ${ }^{29}$, который вошел в состав Кутаисской губернии в качестве округа ${ }^{30}$. Однако, впоследствии Сухумский округ, также как и Закатальский, стал отдельной административной единицей в Закавказье.

9 декабря 1867 был принят Высочайший указ «О преобразовании управления Кавказского и Закавказского края", в соответствии с которым в Закавказье была образована пятая губерния - Елисаветпольская с губернским центром в Елисаветполе, в состав которой вошел ряд территорий Тифрлисской, Эриванской и Бакинской губерний ${ }^{31}$.

После Русско-турецкой войны 1877-1878гг. к Российской империи отошли ряд территорий. Из земель Карсского и Чилдырского санджаков была образована Карсская область со статусом, приравненным к губернии ${ }^{32}$. Из части территории Аджарского санджака была образована Батумская область, статус которой также был приравнен к губернии ${ }^{33}$. В 1883 году Батумская область была упразднена и её территория была включена в состав Кутаисской губернии. Но в 1903 году она снова была образована из Батумского и

${ }^{29}$ Географическо-статистический словарь Российской империи. Т. IV, СПб, 1873, стр. 806-807.

30 «Сухумский округ». Энциклопедический словарь. Издатели Брокгауз Ф.А. (Лейпциг), Ефрон А.И. (С.-Петербург). Том 32, Санкт-Петербург, 1901, стр. 149-150.

31 Полное собрание законов Российской империи. Собрание второе. Том XLII, отделение второе, 1867, Санкт-Петербург, 1871, стр. 383.

32 Подробнее о данной административно-территориальной единице см., в частности, «Карсская область». Энциклопедический словарь. Том 15А, Санкт-Петербург, 1895, стр. 599-602.

33 Энциклопедия морских и военных наук, под редакцией генераллейтенанта Леера. Том I, Санкт-Петербург, 1883, стр. 367. 
Артвинского округов Кутаисской губернии ${ }^{34}$.

Таким образом, к началу Первой мировой войны в административно-территориальном плане Закавказье состояло из четырех губерний - Бакинской, Елисаветпольской, Эриванской, Тифлисской и Кутаисской, двух областей - Карсской и Батумской, двух округов - Закатальского и Сухумского. Что касается Северного Кавказа, то здесь были две губернии - Черноморская с центром в Новороссийске и Ставропольская с центром в Ставрополе, и три области - Кубанская с центром в Екатеринодаре (современный Краснодар), Терская с центром во Владикавказе и Дагестанская с центром в Темир-Хан-Шуре (современный Буйнакск).

Все губернии, области и округа Северного Кавказа и Закавказья в свою очередь входили в состав Кавказского наместничества, которое несколько раз создавалось и упразднялось ${ }^{35}$. Последний раз Кавказское наместничество было образовано в 1905 году высочайшим указом императора Николая II Сенату ${ }^{36}$ и просуществовало вплоть до падения самодержавия.

Таким образом, как уже отмечалось, к началу XX века и вплоть до распада Российской империи этнонациональный подход формирования административно-территориального деления был постепенно заменен на территориальногеографический принцип и все крупные административные единицы Кавказа отражали именно данную стратегию.

\footnotetext{
34 «Батумская область». Энциклопедический словарь, дополнительный том I, Санкт-Петербург, 1905, стр. 225.

35 Макиевский-Зубок Н.Г. «Кавказ и кавказские наместники». Вестник Европы, том 1., кн. 2, гл. 1-2, 1906, стр. 613-653; том 2., кн. 3, гл. 3-4, 1906, стр. 91-130.

36 Полное собрание законов Российской империи. Собрание третье. Том XXV, отделение первое, 1905, Санкт-Петербург, 1908, стр. 149.
} 
Тем не менее, в регионе все же оставались ряд мелких административно-территориальных единиц, фрормированных по этнонациональному принципу. Так в Дагестанской области вплоть до распада Российской империи существовали Аварский и Даргинский округ. Большинство населения Аварского округа составляли аварцы ${ }^{37}$, в Даргинском округе большинство населения также составляли даргинцы, доля которых превышала 92\% от общей численности населения этого округа ${ }^{38}$. Здесь следует отметить, что ареал проживания этнических аварцев и даргинцев намного превышал территорию этих округом. Тем не менее, эти единицы были единственными на Кавказе административно-территориальными образованиями, сохранившими свое этническое название, и существование этих округов было, скорее, исключением, подтверждающим правила. Все другие аналогичные округа, существовавшие на Кавказе, в частности, Кабардинский, Осетинский, Ингушский, Чеченский, Ичкеринский, Кумыкский округа Терской губернии ${ }^{39}$, к 1871 году были переименованы или преобразованы в Нальчикский (Георгиевский), Владикавказский, Грозненский, Кизлярский, Хасавюртовский, Веденский округа ${ }^{40}$.

Весьма четкая стратегия была выработана и в плоскости управления губерниями. Анализ состава губернской ад-

\footnotetext{
37 «Аварский округ». Энциклопедический словарь. Том I, Санкт-Петербург, 1890, стр. 52.

38 «Даргинский округ». Энциклопедический словарь. Том X, СанктПетербург, 1893, стр. 136.

39 Полное собрание законов Российской империи. Собрание второе. Том XXXVII, отд. первое, 1862, Санкт-Петербург, 1865, стр. 498-499.

40 Более наглядно и подробнее о границах и этническом составе этих единиц см., к примеру, Цуциев А.А., Атлас этнополитической истории Кавказа (1774-2004), Москва, 2007, стр. 8, 9.
} 
министрации убедительно свидетельствует, что во всех звеньях ее господствовали дворяне, от 100\% (губернаторы) до $66,6 \%$ (прокуроры), а по национальному составу преобладали русские - 84,5\%, остальные были представлены немцами и отчасти поляками ${ }^{41}$. Подавляющее большинство губернаторов (96,7\%) были дворянами по происхождению, почти 85\% были православными, среди вице-губернаторов православные составляли 93,6\% ${ }^{42}$.

\section{Этнонациональная геополитика Закавказья}

Закавказье, как уже отмечалась, всегда отличалось пестрым этнонацинальным составом, что, естественно, учитывалось царским правительством при проведении административно-территориальной политики. Однако для достижения более действенного геополитического эффректа, особенно учитывая этнополитическую специфику региона, интересы и цели региональных и глобальных держав, параллельно с административно-территориальной политикой, необходимо было вести и соответствующую политику в этнонациональной плоскости.

Особенно актуальной была данная проблема в Восточном Закавказье. Здесь царские власти столкнулись с весьма специфической ситуацией. Дело в том, что на момент инкорпорации Закавказья в состав Российской империи здесь проживала достаточно большая масса тюркоязычного населения, которая все еще не составляла единого народа. Как уже было отмечено ранее, связано это было со спецификой Ирана периода Сефевидов и последующих династий, когда тюркский элемент не консолидировался в единый этнос,

\footnotetext{
41 Зайончковский П.А. Правительственный аппарат самодержавной России в ХІХ в. Москва, 1978, стр. 176, 177.

42 Зайончковский П.А. Указ.соч., стр. 214, 215.
} 
сохраняя в качестве основы идентичности шиизм и племенную принадлежность, что давало возможность поддержания внутреннего единства Ирана и двуядерности его титульного государствообразующего этнонационального компонента.

Однако если в составе Персии это было стратегически важным императивом, относительно стабильным состоянием, одним из ключевых компонентов безопасности страны и гарантией ее единства, то с такой конфигурацией в составе России дело обстояло иначе. Могла сложиться ситуация, при которой в среде достаточно многочисленного этнического массива, оторванного от своего бывшего государства и лишившегося соответственно доминирующего положения в его этнополитической структуре, начались неизбежные процессы новой этнополитической «кристаллизации».

Эта кристаллизация могла вызвать новые и нежелательные проблемы геополитического характера. Несмотря на этническую разношёрстность, к моменту вхождения Восточного Закавказья в состав Российской империи у вышеуказанного этнорелизиозного массива сохранялись две основные составляющие этнонациональной идентичности язык и религия. В составе Ирана, как уже отмечалось, доминирующим был религиозный компонент - шиизм, а племенная и языковая принадлежность скорее были атрибутами субэтничности. В составе России, оторванный от своей прежней среды, шиитский этнорелигиозный массив, естественно, мог стать тяготеющим к Ирану.

С другой стороны, в составе России, несравнимо более передовой в промышленном, экономическом и культурном плане стране, чем региональные государства, язык, как составляющая этнонациональной принадлежности, мог стать равнозначной с религией составляющей идентично- 
сти, а затем и стать определяющим его компонентом, особенно в век бурного его развития в XIX веке. В таком случае, мог начаться геополитический и этнокультурный дрейфр тюркского этнополитического массива Восточного Закавказья в сторону Турции.

И первый, и второй сценарий был не в интересах России, поэтому необходимо было сделать все возможное для того, чтобы предотвратить обе эти возможности.

Но принятие важных решений геополитического характера, особенно в стратегически важнейших регионах, требовало тщательного изучения этнокультурной специфики, социально-бытового положения, истории и других аспектов жизни народов, населяющих данное пространство, в частности тех, которые были в центре особого внимания.

Надо отметить, что изучение народов и описание этнонационального состава населения Восточного Закавказья началось еще до присоединения региона к России. Весьма интересные сведения о Восточном Закавказье имеются в первой части работы участника посольства Артемия Петровича Волынского, посланного Петром I в Персию в 1715-18 гг., шотландцем Джоном Бельем. Вот один из отрывков, касающихся этнонацинального состава Ширвна: «Городъ Шамахія лежитb около сороковаго степеня Сьверныя широты. Древле составляль онъ часть Мидіи, нынь онъ находится Столицею великія Провинціи, называемыя Ширванъ... Наибольшую часть жителей составляють Персы: находится также тамъ знатное число Грузинцовъ и Армянъ. Народъ тамошній говорить по Турецки; но чиновные люди по Персидски. Воздухъ тамъ гораздо здоровье, нежели въ другихъ городахъ стояіщихъ при Каспійскомъ морь» ${ }^{43}$.

43 Белевы путешествия чрезъ Россию в разныя асиятскія земли; а именно: в 174 
Затем тюркские наречия Кавказа в российском научном обществе стали рассматриваться как диалекты татарского языка. Чем было это обусловлено однозначно сказать трудно. Возможно, это было связано с тем, что с началом монголо-татарского нашествия и на протяжении последующих столетий для русского мира основным представителем тюрков были татары, язык которых был тождественен практически всем тюркским диалектам. Так, в одном из официальных изданий, описывающих Закавказье, указано, что «К татарскому племени принадлежат: 1) татары, 2) турки (османли), 3) сельджукские турки, 4) казахи или казахцы»"4.

Весьма интересные этнографические описания Закавказья оставил Иоганн Антон Гюльденштедт, российский естествоиспытатель и путешественник, происходивший из балтийских немцев, который одни из первых европейцев исследовал быт и культур у народов Северного Кавказа ${ }^{45}$ и побывал в Закавказье. Говоря о татарских народах Восточного Кавказа, Гюльденштедт разделяет их на три группы: кумыкские, терекеменские или трухменские и ногайские. Он указывает, что они говорят на одном татарском языке, весьма распространенном на Кавказе, хотя языки эти весьма различны. Гюльденштедт сравнивает сходство турецкого, терекеменского, кымыкского и нагайского наречий со сходством итальянского, испанского и португальского язы$\operatorname{KOB}^{46}$.

Испаганъ, въ Пекинъ, в Дербентъ и Константинополь, Перевелъ съ Французскаго Михайло Поповъ. Часть первая, Санкт-Петербург, 1776, стр. 59.

${ }^{44}$ Евецкий О. Указ. соч., стр. 32.

45 Подробнее о жизни и деятельности этого исследователя см., например, Копелевич Ю.Х. Иоганн Антон Гильденштедт 1747-1781, Москва, 1997.

${ }^{46}$ Географическое и статистическое описание Грузии и Кавказа из Путешествия Г-на Академика И.А. Гильденштедта чрез Россию и по Кавказским 
Немецкий ученый и путешественник Фридрих Маршал фон Биберштейн, поступивший на русскую службу в 17981799гг., объехал Кавказ и подготовил исследование, содержавшее интересные сведения о топографии, истории, экономике, населении, фрлоре и фрауне региона. Биберштейн указывает, что население Восточного Закавказья весьма пестрое. Он указывает о наличии здесь достаточно большого тюркского массива и считает их татарами, язык которых отличается от языка крымских татар так, как малороссийский язык от великорусского. Но в антропологическом плане Биберштейн считает, что татары представляют собой смешанный тип, который вобрал в себя черты соседних народов, в частности грузин и армян ${ }^{47}$.

Российский учёный-географр Афранасий Щекатов, побывавший в тот же период на Кавказе, также подготовил достаточно интересный труд - географический Словарь Российского государства, вышедший в свет в начале XIX века. Перечисляя народы Восточного Кавказа, Щекатов также упоминает татар, которых разделят на следующие группы: кумыки, ногайцы и трухменцы или туркоманские татары ${ }^{48}$.

После этого, особенно с присоединением региона к Российской империи, носителей тюрко/татарского языка в Закавказье в России стали именовать татарами. Причем в Персии этого не произошло, и там они остались в своем прежнем статусе. Постепенно, переняв российскую этимоло-

горам, в 1770, 71, 72 и 73 годах. Санкт-Петербург, Императорская Академия наук, 1809, стр. 101.

${ }^{47}$ Von Bieberstein F.A.M., Beschreibung der Länder zwischen den Flüssen Terek und Kuram Caspisch en Meere, Frankfurt, 1800, S. 108, 109.

48 Щекатов А. Словарь географический Российского государства. Ч. 3, Москва, 1804, стр. 22. 
гию, тюрок Закавказья начали называть татарами и в других странах.

Хотя на первых порах с этим согласны были не все. Так, в официальном документе под названием «Обозрение российских владений за Кавказом, в статистическом, этнографическом, топографическом и фринансовом отношениях» за 1836 год указано следующее: «Здесь нельзя не привести весьма важного замечания, что, несмотря на превосходство татар и монголов, наложивших свой тип на всех тамошних мусульман, не встречается названия татар или монголов, хотя русские вообще именуют их татарами» ${ }^{49}$. Далее там же указывается, что господствующий язык в Ширване есть туркоманский, употребляемый вообще в Адербаэджане (соседней с Закавказьем провинцией Персии - Д.Б.) и называемый у нас обыкновенно татарским. Он столько сходен с турецким, что оба народа могут друг друга понимать ${ }^{50}$. В документе подчеркивается также: «Надобно заметить, что общепринимаемое в Закавказье наименование тамошних мусульман татарами неосновательно, ибо их язык весьма различествует от татарского, хотя, впрочем, оба они имеют один корень - язык чагатайский» ${ }^{51}$.

Практически в таком же духе были и данные, опубликованные по результатам путешествия известного русского тюрколога и востоковеда Ильи Николаевича Березина по восточным странам, которое состоялось в 1824-1856гг. По мнению ряда исследователей, это было первое чисто науч-

\footnotetext{
${ }^{49}$ Обозрение российских владений за Кавказом, в статистическом, этнографическом, топографическом и финансовом отношениях. Часть III, СанктПетербург, 1836, стр. 6.

50 Указ. соч., стр. 78-79.

51 Указ. соч., стр. 78.
} 
ное путешествие по странам Востока ${ }^{52}$. Так, изучая языки Баку, Березин отмечал, что здесь говорили на тюркском и татском персидском наречиях, а местное тюркское наречие он квалифицировал, как переход от Дербентского наречия к Адербиджанскому ${ }^{53}$. Тюркский язык Березин сгруппировал в три главные «ветви»: "джагатайская» или восточная, наиболее древняя из трех; «татарская» или северная и «турецкая» или западная. В джагатайскую ветвь он включил уйгурский, команский джагатайский, узбекский, туркменский и казанский (книжный) диалекты; в татарскую ветвь он включил киргизский, башкирский, ногайский, кумыкский, карачайский, каракалпакский, мещерякский и сибирский диалекты; в турецкую ветвь он включил дербентский, адербиджанский, крымский, анатоли-малоазиатский, румели-стамбульский диалекты ${ }^{54}$.

Известный русский писатель и драматург Алексей Феофрилактович Писемский, побывавший в Баку в 1886 году, пишет следующее: «Мне объяснили, что все это татары, хоть они совершенно не похожи на татар астраханских, горский лезгинский характер ярко отпечатывается и в одежде, и в стройном складе тела, и в каком-то благородном и воинственном выражении лиц ${ }^{55}$.

\footnotetext{
52 Кузнецова Н.А., Данцинг Б.М. И. Н. Березин - путешественник по Закавказью, Ирану и Ближнему Востоку, Краткие сообщения Института востоковедения. Вып. XXII, Москва, 1956, стр. 100.

${ }_{53}$ Обзор трехлетнего путешествия по Востоку магистра Казанского университета И.Н. Березина Журнал министерства народного просвещения (ЖМНП), ч. LV, Санкт-Петербург, 1847, стр. 2.

54 Указ. соч., стр. 15, 16.

55 Писемский А.Ф. Собрание сочинений в девяти томах. Том 9., Москва, 1959, стр. 514.
} 
Интересно, но введение в оборот понятия «адербиджанское наречие» также было исключительно российским лингвистическим нововведением, до того нигде и никогда не использовавшимся. Есть даже имена людей, сделавших это. Ряд исследователей считают, что первым это сделал выдающийся российский востоковед Александр Касимович Казем-Бек, одним из самых известных трудов которого является опубликованная в 1840-х годах в Казани "Общая грамматика турецко-татарского языка». Сам ученый относил адербиджанское наречие к татарскому языку ${ }^{56}$.

Известный российский востоковед Борис Андреевич Дорн в своей рецензии на «Грамматику турецко-татарского языка», представленную Казем-Беком на соискание Демидовской премии указывал следующее: «Особенной признательности знатоков заслуживают поучения о дербентском, а еще более о доселе почти вовсе неизвестном, но теперь выясненном Мирзою Казем-Беком, адербиджанском наречии, потому что оба имеют довольно особенностей, поощряющих к дальнейшим изысканиям, и преимущественно адербиджанский, весьма важный для наших кавказских училищ. Можно даже по справедливости сказать, что одни замечания, сообщаемые Казем-Беком об этом наречии, уже придают его книге особенное достоинство» ${ }^{57}$.

Другие считают, что впервые термин «адербиджанское наречие» использовал писатель-декабрист Александр

\footnotetext{
${ }_{56}$ Казем-Бек Мирза, Общая грамматика турецко-татарского языка. Казань, 1846. стр. 7, 10.

57 Дорн Б.А. Грамматика турецко-татарского языка, составленная Мирзою Александром Казем-Беком. Журнал Министерства народного просвещения, 1841 , ч. 32, стр. $86,87$.
} 
Александрович Бестужев-Марлинский ${ }^{58}$, работы которого о Кавказе относятся к 30-м годам XIX века. В одной из своих работ он также указывал, что татарский язык Закавказского края мало отличен от турецкого, и с ним, как с французским в Европе, можно пройти из конца в конец всю Азию59. Название наречию было дано, как уже отмечалось выше, в честь исторической Атропатены/Азербайджана, в Персии, граничащей с Закавказьем ${ }^{60}$.

Однако отнесение языка тюркоязычного населения Закавказья к татарскому, а самих его носителей - к татарам, пусть даже было спорно и неправильно с научной, исторической, культурной и ряда других точек зрения, было целесообразно с геополитической точки зрения. «Татаризация» тюркоязычного массива Закавказья давала возможность одновременно решить несколько ключевых геополитических задач.

Основным императивом здесь выступало уже упомянутое недопущение геополитического и/или этнокультурного дрейфра тюркского массива Восточного Закавказья в сторону Турции или Ирана. Классификация языка тюрок Закавказья в качестве турецкого дало бы серьезный толчок для самоидентификации представителей данного этнокультурного массива в качестве турок с постепенным их отуречиванием и геополитической ориентацией на Турецкую импе-

\footnotetext{
58 Керимов Э.И. Очерки истории этнографии Азербайджана и русскоазербайджанских этнографических связей (XVIII-XIХвв.). Баку, 1985, стр. 60.

${ }^{59}$ Марлинский А. Письма из Дагестана. Полное собрание сочинений, ч. II, Санкт-Петербург, 1837, стр. 186.

${ }^{60}$ См., например, Березин И.Н. Путешествие по Северной Персии. Казань, 1852, стр. 90; «Кавказские языки». Энциклопедический словарь, том ХІІІА, Санкт-Петербург, 1894, стр. 818.
} 
рию. Отождествлять их с персами, но говорящими на тюркском языке, в свою очередь, мог дать соответствующий толчок к иранизации данного массива, что, учитывая наличие в Восточном Закавказье сохранивших свою этнонациональную идентичность иранских народов, могла сделать иранский компонент доминирующим в численном отношении элементом региона. Это не только усилило бы влияние Персии, а через нее и геополитических соперников России в регионе, но и нарушало бы один из ключевых принципов контроля над стратегически важнейшей территорией посредством поддержания этнонациональной и культурнорелигиозной мозаичности и многообразия, снижающего вероятность возможной консолидации разношерстного массива в единую силу.

«Татаризация» же была весьма подходящим решением, дающим возможность решить вышеуказанные проблемы. Из говорящего на одном из тюркских языков разношерстного этнического массива, вобравшего в себя разные этносы, создавался единый этнос под названием кавказские татары. Он отрывался от своего кызылбашско-иранского прошлого, но в то же самое время, не вливался в турецкоосманский этнокультурный массив. Хотя в Российской империи были разные татарские народы и субэтносты, такие как татары казанские, сибирские, крымские, астраханские, алтайские, горские и т.д., они не составляли единого народа, отличаясь друг от друга антропологически, культурой, бытом, религией. Кроме того, ареал распространения татарских народов географически не составлял единого целого и их разделяли достаточно большие расстояния. Таким образом, имея такие различия и проживая на больших расстояниях друг от друга, татарские этносы не могли сорормиро- 
вать единого народа со своей единой территорией. Это делало татаризацию тюрков Закавказья наиболее подходящим и наименее опасным с геополитической точки зрения.

В данном контексте необходимо отметить, что тюрков Персии, говорящих на одном наречии с тюрками Восточного Закавказья, в российских источниках продолжали именовать «тюрками». Термин же «кавказские татары» к ним не применялся. Хотя, иногда можно было встретить наименования «тюрко-татары». Так, уже упомянутый известный русский ученый-тюрколог и востоковед Илья Березин, описывая население исторической Атропатены-Азербайджана в своем труде «Путешествие по Северной Персии», изданной в Казани в 1852 году, указывал, что значительную часть населения этой провинции составляли тюркские и курдские племена ${ }^{61}$. В исследовании капитана Генерального штаба российской армии Л.К. Артамонова «Северный Азербайджан. Военно-географический очерк», рассматривающий население северной, пограничной с Закавказьем, части исторического Азербайджана, тюркский этнический массив региона был представлен в качестве тюрко-татарских племен, где племенная обособленность была весьма сильна, особенно среди кочевников ${ }^{62}$.

Кроме того, и термин «адербиджанское наречие» не нашел широкого применения в научных, особенно, официальных и политических кругах. Это было понятно, ведь в таком случае центральным элементом здесь выступал исторический Азербайджан в Персии и научный подход здесь мог незаметно получить политический оттенок, чего надо было всячески избегать.

\footnotetext{
${ }^{61}$ Березин И.Н. Указ. соч., стр. 89.

62 Артамонов Л. Указ. соч., стр. 21.
} 
И такой подход был действительно правильным и одним из самых эфффективных геополитических решений со стороны царских властей не только в контексте кавказской политики, но и этнополитики в целом, ставших симбиозом научных и политических решений, спонтанности, трансформировавшейся в четкую государственную политику.

Интересно отметить, что российские ученые-этнографы придавали важное значение грамотному использованию этнографии в политических целях, выявляя при этом ошибки властей и их политические последствия. Так, в одном из исследований конца XIX века указано следующее: «Незнакомство с этнографическими данными, непонимание быта, состояния и потребностей народа было у нас уже причиною многих административных и законодательных ошибок... Благодаря этим ошибкам, например, буряты из шаманистов сделались буддистами, а киргизы-магометанами, чем, можеть быть, отрезан навсегда путь к их слиянию с русскимъ народом. Вместо того, чтобы прииять меры к их обращению в христианство и к противодействию влиянию буддизма и магометанства, у насъ было признано, что буддизм и магометанство, во всяком случае, лучше шаманизма., и тем косвенно была дана возможность утвердиться этимъ религиям, которые между тем способны противостоять гораздо крепче христианству, чем первобытныя верования» ${ }^{63}$.

Но в случае с тюрками Закавказья и их татаризацией, как уже было отмечено, центральные власти империи сделали правильный шаг с геополитической точки зрения. Одновременно, надо отметить, что данный шаг имел и фунда-

${ }^{63}$ Анучин Д.Н. О задачах русской этнографии (Несколько справок и общих замечаний). Москва, 1889, стр. 34, 35. 
ментальные последствия для Закавказья и всего региона в целом.

В первую очередь данный процесс, естественно, затронул самих тюрков Закавказья. Именно «татаризация» тюркских племен и групп данного региона создала основу создания из них в будущем единого народа. Как уже отмечалось, данная политика отрывала тюркский массив от Ирана, мешала переориентации на Турцию, но, в то же время не могла влить его в единый татарский этнонациональный массив. В данном случае были запущены механизмы его обособления в некое единое образование. Российские власти добились того, что закавказские или кавказские татары, как ранее тюрки Персии, стали этнонациональным массивом и приобрели отличную от турок и персидских тюрок идентичность.

Задача, которую необходимо было решить, представлялась одновременно и относительно легкой и достаточно трудной. Относительная легкость заключалась в том, что тюркский массив, как уже отмечалось, не был единым и консолидированным народом, чему препятствовали этноплеменное разнообразие, сильные миграционные и переселенческие потоки различных народов и племен. Поэтому не удивительно, что нередко понятие родины у тюрков ограничивалось своим городом или магалом ${ }^{64}$. Писатель и мыслитель Мирза Фатали Ахундов (1812-1878гг.) в докладной записке попечителю Кавказского учебного округа, написанной в 1852 году, указывал следующее: «Закавказский край, в котором татарское племя числом превышает других его обитателей, до владычества России находился под влиянием персидских государств или турецких султанов. В первом

${ }^{64}$ История Азербайджана. Том 2, стр. 273. 
случае письменность татарского племени производилась на персидском языке, а во втором на турецком, который в настоящее время разительно отличается с закавказским татарским наречием, а потому татарское племя доселе не имеет собственной литературы, и не отыщется книги, сочиненной в оригинале на чисто народном татарском языке; если же окажется что-либо, написанное по-татарски, то это верно перевод с какого-нибудь другого языка, написанный напыщенными фрразами и другими ненатуральными фразами по духу персидского, арабского или турецкого языков, следовательно, по таким сочинениям, или лучше сказать переводам, невозможно постичь дух и свойство татарского языка, изучить его в том основании, в каком он существовал в народе, судить о грамматических правилах и составить даже руководство для его изучения из подобных сочинений» ${ }^{65}$.

Bce это упрощало прививание новой идентичности этому массиву. Однако, были и трудности. Так, у тюркского массива сохранились такие традиционные компоненты идентичности, как религия, которая была зачастую преобладающим ее компонентом среди целого ряда племен. С другой стороны, слабая и шаткая татарская идентичность в будущем создала и благодатную почву для проникновения таких националистических идеологий, как пантюркизм.

В этом контексте центральные власти активно помогали формированию новой кавказской татарской интеллигенции и просвещению татар. Надо отметить, что за относительно короткий отрезок времени ядро данной интеллигенции было сорормировано. Именно эти деятели и стали в будущем одной из важнейших основ культуры нового народа.

65 Ахундов М.Ф. Избранные философские произведения. Баку, 1953, стр. 350. 
Эти деятели высоко оценивали роль России в жизни их народа. Так, Мирза Фатали Ахундов в середине XIX века отмечал, что Россия объективно способствовала сохранению национальности татар региона ${ }^{66}$. Он также отмечал, что именно при российском владычестве впервые открыли школы, где преподавание велось на татарском языке, а последний наряду с другими предметами начал изучаться как специальная дисциплина» ${ }^{67}$.

Другой деятель Гасанбек Зардаби (1837-1907гг.) отмечал, если хотите, чтобы татарская нация жила, достигла прогресса, овладела науками и культурой, то дайте ей язык, который они потеряли. "Они не понимают ваши слова. Найдите их язык, дайте им, чтобы они писали, продвигались вперед, учились в школах, получали образование на родном языке» ${ }^{68}$.

Мирза Фатали Ахундов, затрагивая данный вопрос, писал следующее: «Если мусульмане в российских владениях будут пропитаны идеями Кемал-Уд-Довле*, то они непременно почувствуют отвращение к мусульманским деспотам... перестанут дичиться и чуждаться русских, под покровительством которых их жизнь, собственность и честь совершенно гарантированы, между тем, как их собратья в Персии и Турции находятся в жалком положении и величайшей нищете; они сольются с русским народом, исчезнет навсегда между ними дух франатизма и мюридизма, проис-

\footnotetext{
${ }^{66}$ Ахундов М.Ф. Сочинения. Том III, Баку, 1955, стр. 22.

67 Там же.

68 Заманов А. Соратники. Баку, 1979, стр. 83 (на азерб. языке).

* «Письма Кемал-уд-Довле» известные также как «Три письма индийского принца Кемал-уд-Довле к персидскому принцу Джелал-уд-Довле и ответ на них сего последнего». Трактат Мирзы Фатали Ахундова, написанный в 1865 году и считающийся одним из самых значительных его произведений.
} 
текающий из религиозных убеждений, и дух стремления к эмиграции в Турцию, где мусульмане по слепому фанатизму предполагают спасение души под владычеством мусульманского государя; равно исчезнет охота к пилигримству в Мекку, куда ежегодно шляется миллион из Кавказского края без всякой пользы» ${ }^{69}$.

Таким образом, получению современного русского образования также отводилось важная роль в формировании нового народа. Как отмечал уже упомянутый видный ученый М. Казем-Бек: «Россия, будучи поставлена в такие близкие отношения к Востоку должна преимущественно перед другими странами нести на своих могучих плечах великое дело просвещения восточных народов» ${ }^{70}$. Оценивая значение образования для развития края, предпоследний кавказский наместник И.И. Воронцов-Дашков (1837-1916гг.) отмечал: «Несомненно, что правильно поставленная русская народная школа, с началами грамотности на материнском языке, является первейшим средством для воздействия на мусульман русским мировоззрением. Она спасает их от вредной с государственной точки зрения пропаганды панисламизма и пантюркизма в школах с турецкими преподавателями и учебниками, проникнутыми нерусскими идеями, и на языке преподавания, чуждом населению, в тех частных мусульманских школах, куда население посылает своих детей за неимением достаточного количества русских школ» ${ }^{71}$.

69 Великая дружба азербайджанского и русского народов. Книга первая. Баку, 1964, стр. 175.

70 Против буржуазных фальсификаторов истории и культуры Азербайджана. Баку, 1978, стр. 32.

71 Всеподданнейший отчет за восемь лет управления Кавказом графа И.И. Воронцова-Дашкова. Санкт-Петербург, 1913, стр. 31. 
Однако, как уже отмечалось выше, фрормирование единого кавказского татарского этноса не было полностью завершено и национальная идентичность, в том числе и у новообразованной интеллигенции, была симбиозом новой этничности и ислама. Так, известный татарский поэт Аббас Ага Гаибов (Назир) (1849-1919гг.) в своем письме Л.Н. Толстому от 24 февраля 1909 года пишет следующее:

«Милостивый государь графр Лев Николаевич! Желая ознакомить моих единоверцев-мусульман с вашими произведениями я, как мусульманский поэт, имею счастье перевести стихами на татарский язык сочинение Ваше под заглавием «Много ли человеку земли нужно?». А потому почтительнейше прошу благосклонного разрешения Вашего на печатание и распространение означенного перевода» ${ }^{72}$. Как видно из письма, поэт, яркий представитель новой интеллигенции, считает себя мусульманским поэтом и кавказским татарином одновременно. Причем, здесь ислам является не только атрибутом религиозной принадлежности, но и этнической, к которой уже прикрепилось татарская составляющая.

Надо отметить, что впервые в истории тюрков Закавказья понятие «миллиет» (нация) ввел в употребление именно писатель-просветитель Мирза Фатали Ахундов в 70-х годах XIX века ${ }^{73}$, который параллельно также жестко критиковал и косность ислама. Прогрессивный публицист Гамзат бек Ширванский (1884-1912гг.) в одной из своих статей, посвященных творчеству Мирза Фатали Ахундова, подчеркнул следующее: «Он смело сбросил покров с мусульманского

\footnotetext{
72 Письмо Аббас Ага Гаибова Л.Н. Толстому, 24 февраля 1909 года. Московский музей Л.Н. Толстого, инв. N48481.

${ }^{73}$ История Азербайджана. Том 2, стр. 276.
} 
тела и выставил на всеобщее осмеяние все наши недуги, язвы, недостатки. Мусульманство содрогнулось» ${ }^{74}$.

\section{Бакинская нефть. Геополитические и внутрипо- литические аспекты}

Интересно, но консолидации тюркского массива в единую этнонациональную общность одновременно способствовал и препятствовал ряд сильнейших течений как внутреннего, так и внешнего характера. Одним из ключевых подобного рода компонентов стала бакинская нефть. Углеводородное сырье Апшерона в корне изменила всю геополитику региона, сделала Кавказ, особенно Восточное Закавказье, одним из основных глобальных геополитических театров, к которому все активнее стало приковываться внимание глобальных игроков в лице великих держав и крупного бизнеса.

Проникновение внешних сил затрагивало политическую, экономическую, культурную, социальную и практически все сореры жизни региона и живущих там народов. Все это, естественно, накладывало свой отпечаток и на этнополитические процессы в регионе.

Конец XIX - начало XX века стал периодом бурного развития промышленности, где ведущую роль начали приобретать энергоносители, в том числе и нефть. Кто обладает нефтью - обладает и в гораздо более широком смысле военной мощью ${ }^{75}$ и данный подход действительно стал одним из главных императивов геополитики, причем на десятилетия вперед.

${ }_{74}$ Ширванский Гамзат бек, Мирза Фатали Ахундов. Газета «Закавказье», N 272, 1911.

75 Вейдемюллер К.Л. Война за нефть. Плановое хозяйство. № 6, 1928, стр. 213. 
Нефть в Баку добывалась издревле, но превращение ее в важнейший экономический и геополитический компонент начался именно со второй половины XIX веке. До начала 1880-х годов лидирующие позиции на мировом рынке в данной сфере принадлежали Соединенным Штатам Америки. В 1872 году на долю США приходилось около 81\% мировой добычи нефти, что в 34 раза превышало объемы добычи нефти в России ${ }^{76}$. До середины $1870-x$ годов на российских рынках также господствовала американская нефть, хотя доля Баку начала постепенно возрастать и в 1872 году вывоз керосина из Баку во внутренние города России составил 454 тыс. 689 пудов, или около 20\% всего вывоза этого продукта в Россию ${ }^{77}$.

Затем бакинская нефть и нефтепродукты начали вытеснять американскую нефть с российских рынков. К 1899 году Баку дал более половины всей мировой добычи нефти и вышел на первое место, оставив позади США, Аргентину, Перу и нефртедобывающие страны ${ }^{78}$. В 1901 году бакинский нефтяной район давал 95\% общеимперской добычи нефти (667,1 млн пудов), затем следовала Терская область (около 34,7 млн пудов), а крупнейшими потребителями бакинского керосина после России стали Англия, Османская империя и $\Gamma$ реция $^{79}$. Наглядной была и дешевизна бакинской нефти.

На фооне развития нефтяной отрасли, в основном ввиду миграции, росло и население города. Если в 1850 году население Баку и всего бакинского уезда составляло менее

\footnotetext{
${ }^{76}$ Petroleum Facts and Figures, New York, 1959, pp. 40-41.

77 Присоединение Азербайджана к России и его прогрессивные последствия в области экономики и культуры. Баку, 1955, стр. 182.

78 Мир-Бабаев М.Ф. Краткая история азербайджанской нефти. «Азернешр», Баку, 2009, стр.199.

79 Там же, стр. 40, 44.
} 
35 тыс. человек ${ }^{80}$, то в 1913 году одно население города Баку в пределах его муниципальной черты составило 214 тыс. 679 человек, увеличившись по сравнению с 1903 годом на почти 80 тыс. человек или 49,3\%81. Как писал в то время лидер большевиков В.И. Ленин, город Баку из ничтожного города сделался первоклассным в России промышленным центром ${ }^{82}$.

Кардинально изменился и этноконфессиональный состав города. Если в 1850 году мусульмане составляли более 94\% населения Бакинского уезда, православные - 4\%, армяне $-1,6 \%{ }^{83}$, то в 1913 году население города Баку по национальностям распределялось следующим образом: русские - 76222 человек (36\%), татары кавказские - 45972 (21,3\%), армяне - 41686 (19,5\%), персы - 25097 (11,8\%), евреи - 9689 (4,55\%), грузины 4077 (1,9\%); немцы - 3280 $(1,5 \%)$; татары казанские - $2346(1,1 \%) ;$ поляки - 1772

80 «Из рапорта бакинского уездного начальника М.Т. Дементьева управляющему Шемахинской губ. Вице-губернатору В.И.Смиттену со сведениями о естественно-географических условиях, населению и экономик уезда от 6 сентября 1850 г.» в Домументы по истории Баку 1810-1917. Главное архивное управление при Совете Министров Азербайджанской ССР, Центральный государственный исторический архив Азербайджанской ССР, Баку, 1978, стр. 23.

81 «Сведения о территории, населении, народном образовании, строительстве Баку-Шолларского водопровода, доходах и расходах г. Баку на 1 января 1914 г., представленные городским головой Л.Л. Бычом и.д. градоначальника П.И. Мартынову от 29 мая 1915 года», в Документы по истории Баку 1810-1917, стр. 29.

82 Ленин В.И., Полное собрание сочинений. Том 3, Москва, 1971, стр. 317.

83 «Из рапорта бакинского уездного начальника М.Т. Дементьева управляющему Шемахинской губ. Вице-губернатору В.И. Смиттену со сведениями о естественно-географических условиях, населении и экономике уезда от 6 сентября 1850 г.» в Документы по истории Баку 1810-1917, стр. 23. 
$(0,83 \%)$; лезгины - $1343(0,49 \%)$; прочие народы Кавказа $476(0,02 \%)$; прочие национальности - $2713(1,27 \%)^{84}$.

Нефрть Баку, экономическое и геополитическое значение этого ресурса вкупе со стратегическим положением региона и бурным развитием города создавали основы для мощнейших социально-политических трансформаций в Закавказье в целом, и в восточной его части в частности. Сюда из других регионов Российской империи и различных стран проникали идеи, активисты и агитаторы, которые вели пропагандистскую работу среди широких масс практически в среде всех этнонациональных и социальных слоях общества.

В результате сфрормировалось множество политических течений, партий и групп, которые в целом можно сгруппировать в два основных вектора: униатство и сецессионизм. Оба этих вектора были разношерстны, как по национальному, так и по социальному и идеологическому признаку, действующие там силы зачастую конфлликтовали друг с другом, нередко выступая в качестве антагонистов. Некоторые силы пропагандировали реформирование страны, ее модернизацию, другие вели борьбу за свержение правящего режима и изменению строя. Но униаты стремились к реализации своих идей в рамках единства страны, рефрормированию различных ее сорер. Сецессионисты, с другой стороны, имели планы по выходу из состава России; некоторые стремились к созданию своих независимых госу-

\footnotetext{
84 «Сведения о территории, населении, народном образовании, строительстве Баку-Шолларского водопровода, доходах и расходах г. Баку на 1 января 1914 г., представленные городским головой Л.Л. Бычом и.д. градоначальника П.И. Мартынову от 29 мая 1915 года», в Документы по истории Баку 1810-1917, стр. 30.
} 
дарств или восстановлению независимости, другие хотели присоединиться к другим государствам, более близким им с этнической или религиозной точек зрения.

Партий и течений, как уже отмечалось, было много. Но лишь два течения, две силы сыграли ключевою роль в дальнейшей истории региона, кардинально изменив ход этой истории.

Одной из этих сил были большевики. В 1900 году в Баку был создан руководящий центр социал-демократических кружков ${ }^{85}$. В Баку осуществляли деятельность знаменитые революционеры, такие как В.3. Кецховели, А.С. Енукидзе, Н.П. Козеренко, А.Г. Эйзенбет, С.Г. Шаумян, Б.М. Кнунянц, М.Г. Меликянц, Л.Е. Гальперин, П.А. Джапаридзе, М.А. Азизбеков, Г.К. Орджоникидзе и многие другие. Но самым известным революционером которому, как будет показано далее, было суждено сыграть ключевую роль в геополитике региона, был Иосиф Сталин, который также вел активную революционную деятельность в Баку. Вот как охарактерезовал бакинский период своей деятельности советский вождь в одном из своих выступлений:

«Я вспоминаю, далее, 1907-1909 годы, когда я по воле партии был переброшен на работу в Баку. Три года революционной работы среди рабочих нефтяной промышленности закалили меня, как практического борца и одного из практических местных руководителей. В общении с такими передовыми рабочими Баку, как Вацек, Саратовец, Фиолетов и др., с одной стороны, и в буре глубочайших конфрликтов между рабочими и нефтепромышленниками - с другой стороны, я впервые узнал, что значит руководить больши-

8525 лет Бакинской организации большевиков (Основные моменты развития Бакинской организации). Баку, 1924, стр. 10. 
ми массами рабочих. Там, в Баку, я получил, таким образом, второе свое боевое революционное крещение. Там я стал подмастерьем от революции» ${ }^{86 .}$

Социал-демократическая организация Баку с первых шагов своей деятельности пропагандировала принципы пролетарского интернационализма. «Рабочие Баку чужды всякой национальной травли. Солидарность пролетариев без различия наций - для них святой завет» ${ }^{87}$. Деятельность большевистских организаций Кавказа получила высокую оценку В.И.Ленина. "У нас и на Кавказе, - писал Ленин в 1913 году, - социал-демократы грузины + армяне + татары + русские работали вместе, в единой социал-демократической организации больше десяти лет. Это не фраза, а пролетарское решение национального вопроса. Единственное решение» ${ }^{88}$.

Одной из важнейших задач, стоявших тогда перед большевиками, было широкое вовлечение в революционную борьбу рабочих-мусульман. С этой целью в конце 1904 года при активном участии П.А. Джапаридзе, А.М. Стопани, Г.Ф. Фонштейна, С.М. Эфендиева в Баку была создана социал-демократическая группа «Гуммет» (Энергия). В дальнейшем руководящую роль в деятельности «Гуммет» играли М.А. Азизбеков, Н.Н. Нариманов, С.Г. Шаумян ${ }^{89}$. В те дни бакинские большевики сообщали Ленину, что ораторы Ба-

\footnotetext{
86 Сталин И.В. Ответ на приветствия рабочих главных железнодорожных мастерских в Тифлисе 8 июня 1926 г. Заря Востока, № 1197, 10 июня 1926.

87 Газета «Листок Борьбы пролетариата». N3, 1 (14) ноября 1903.

88 Ленин В. И. Сочинения. Изд. 4-е, т. 35, Москва, 1950, стр. 58.

89 Очерки истории Коммунистической партии Азербайджана. Баку, 1963, стр. $60,61$.
} 
кинского комитета «выступали во всех районах и говорили на всех туземных языках» ${ }^{90}$.

Бакинский комитет поддерживал в тот период тесные связи с революционными социал-демократами Средней Азии, Дагестана, Северного Кавказа, помогал им в создании социал-демократических кружков и групп, в распространении марксистских идей, налаживании подпольной печатной техники. В Закаспийский край из Баку выезжали партийные работники, посылалась литература. На Северном Кавказе, в Грозном, активную партийную работу проводил член Бакинского комитета партии И.Т. Фиолетов, а по просьбе социалдемократических организаций Дагестана туда направлялись пропагандисты, агитаторы-массовики, пересылалось значительное количество партийной литературы ${ }^{91}$.

Другим важнейшим течением стала идеология пантюркизма. Именно борьба с пантюркизмом и против него стала определяющим компонентом истории Восточного Закавказья начиная со второй половины XIX века вплоть до нашего времени. И с начала XX века до распада СССР одним из основных геополитических и идеологических соперников пантюркизма выступал большевизм или советский коммунизм и ареной их борьбы представляло огромное пространство, включающее Кавказ, Поволжье, Центральную Азию, ряд регионов Сибири. И здесь одним из самых важнейших регионов было именно Восточное Закавказье, своего рода передовая этой борьбы.

Основная идея пантюркизма заключается в объединении всех тюркских народов или тюркского мира в одном государстве, при лидирующей роли Турции. Как ни пара-

\footnotetext{
90 Журнал «Пролетарская революция». N 25, 1925, стр. 35.

91 Очерки истории Коммунистической партии Азербайджана. Стр. 62, 63.
} 
доксально, но идея пантюркизма не является турецкой идеологией. Она разрабатывалась за пределами Османской империи. Авторами идей пантюркизма были европейцы, английские, французские, германские и австрийские правящие круги и их спецслужбы ${ }^{92}$.

Логика создания пантюркизма была весьма проста. Данная политика давала возможность одновременно достичь двух важнейших целей. Во-первых, Турция, жаждущая реванша над европейскими державами за потерю своих владений в Европе, более не рассматривала возврат данных территорий в качестве основной своей задачи и не угрожала европейским странам. Таким образом, можно было повернуть направление возможной турецкой экспансии с Европы и контролируемых великими европейскими державами территорий, ранее завоеванных османами, в сторону Российской империи, под властью которой находилась основная масса тюркских народов за пределами Османской империи. Как писал один из идеологов пантюркизма Мунис Текинальп, он же Моиз Коэн, для создания турецкой цивилизации 12-15 млн. османских турок было недостаточно и объединение 40-50 млн. тюрок, живших за пределами Османской империи, в единое государство было обязательным ${ }^{93}$.

\footnotetext{
92 Подробнее о зарождении пантюркизма, его основоположниках и основных представителях см., например, Demirağ Yelda, Pan-Ideologies in the Ottoman Empire Against the West: From Pan-Ottomanism to Pan-Turkism, The Turkish Yearbook, Vol. XXXVI, 2005, p. 150; Мартиросян A., Заговор маршалов. Британская разведка против СССР. Москва, 2003, стр. 31; Nadir Devlet, İsmail Bey (Gaspıralı), Ankara, Kültür ve Turizm Bakanlığı, 1988; Hakan Kırıml, İsmail Bey Gaspıralı, Türklük ve İslam, Doğu-Batı, N 31, April 2005, pp. 147176; Мухамметдинов Р.Ф. Зарождение и эволюция тюркизма. Казань, 1995.

${ }_{93}$ Cohen Moiz, Türkler Bu Muhârebede Ne Kazanabilirler?, Istanbul, Türk Yurdu, 1330 (1914), s. 3.
} 
Таким образом, Османская империя должна была направить свой взор на российские территории и таким образом в результате столкновения двух империй ослабевали обе, а в выигрыше оказывались великие европейские державы, которые могли в результате этого включить в сферу своего влияния дополнительные территории, подконтрольные Турции.

Это, в свою очередь, исключало бы всякую возможность стратегического и долгосрочного союза между Российской и Османской империями, сценарий, который мог бы стать геополитической катастрофрой для великих европейских держав и создать реальные угрозы их интересам в Европе, Северной Афррике, Индии и других регионах. Одним из самых действенных преград на данном пути был именно пантюркизм.

Пантюркизм также был, возможно, самым действенным механизмом подрыва позиций панисламизма, идеологии, пропагандирующей единение всех мусульман и создание единой исламской державы, которую активно продвигала Османская империя, тем более, что турецкий султан, еще со времени правления Селима I Явуза (1512-1520гг.) был халифом - предводителем правоверных.

Весьма опасались панисламизма британцы, особенно в Индии. Так, после окончательного завоевания Индии Британской империей, местные мусульмане начали проявлять все больше симпатий к Османской империи, связывая с ней и политические надежды. Многие мусульмане даже мигрировали в пределы Турции и удостаивались почестей от самих султанов ${ }^{94}$. Но пантюркизм сотрясал единство и без то-

\footnotetext{
${ }^{94}$ Smith W.C., "The "Ulama" in the Indian Politics", Politics and Society in India, London, 1963, p. 50; Dale S.F., Islamic Society of the South Asian Frontier. The 197
} 
го многонациональной Османской империи и сужал пространство геополитического маневра этой державы, отторгая другие мусульманские нетурецкие народы от главной национальной идеи. В данном контексте создавались соответствующие предпосылки отпада или аннексии территорий с нетурецким мусульманским населением, тем более, что после завершения процесса колонизации они составляли то пространство, которое еще можно было колонизировать. Кстати, ряд исследователей и политиков рассматривал Первую мировую войну именно как возможность захвата территорий Османской империи. Например, Ленин писал следующее: «Из-за чего ведется данная война? Это указано в нашей резолюции (основывающейся на политике воюющих держав, которую они вели десятилетия до войны). Англия, Франция и Россия воюют за сохранение награбленных колоний и за грабеж Турции и пр. Германия за то, чтобы отнять себе колонии и самой ограбить Турцию и пр.. ${ }^{95}$.

Но в то же самое время, турецкий фрактор продолжал оставаться важным и раздавить его отторжением разного рода территорий было неправильно. Пантюркизм давал Турции альтернативу, своего рода пассионарную энергию на десятилетия вперед, которую можно было и надо было использовать в глобальной геополитике, особенно во взаимоотношениях с Россией, тем более, что возможный русскотурецкий союз мог полностью изменить военно-стратегический баланс в мировой политике.

Mappilas of Malabar, 1499-1922, Oxford, 1980, p. 134f.; Haq M.U., Muslim Politics in Modern India, Meerut, 1970, p. 62ff.

95 Ленин В.И. О национальном и национально-колониальном вопросе. Москва, 1956, стр. 365. 
В качестве первого шага к осуществлению на практике пантюркистской идеологии стало формирование уже упомянутой идеологии тюркизма, т.е. идеологии в Османской империи турецкой нации, прививание тюркскому населению Османской империи турецкой национальной идентичности. На первый взгляд может показаться, что задача была из легких. Но на самом деле это был весьма сложный процесс. Достаточно указать, что в то время слово «турок» в Османской империи было одним из оскорбительных выражений ${ }^{96}$. Насаждение тюркизма шло параллельно активной пропаганде пантюркизма. Для осуществления этих планов необходимо было в первую очередь создать общую этническую границу между тюрками Османской империи с Закавказьем и Ираном и «очистить» пространства, заселенные нетюркскими христианскими народами, в частности, армянами, греками, ассирийцами, а также езидами. Это было ключевым условием успешного завершения пантюркистских планов и создания сплошного тюркского этнополитического пространства от Босфора до Сибири. Особую важность здесь приобретала территория, известная тогда как «Турецкая Армения» (Западная Армения). Весьма интересную характеристику важности данного региона дал Иосиф Сталин, дав следующее определение: «Это тот самый «райский уголок», который долгие годы служил (и продолжает служить) предметом алчных дипломатических вожделений Запада и кровавых административных упражнений Востока» ${ }^{97}$.

\footnotetext{
96 История человечества, под общей редакцией Г. Гельмольта. Том V, ЮгоВосточная и Восточная Европа. С-Петербург, 1905, стр. 117, 122.

${ }_{97}$ Сталин И. О Турецкой Армении. Правда, № 227, 31 декабря 1917.
} 
В начале XX века одной из ключевых точек преломления пантюркистской идеологии, если не самой ключевой, стало Закавказье. Здесь одновременно переплелись целый ряд стратегических, географических, этнополитических, экономических и иных факторов. Закавказье был своего рода мостом, геополитической пуповиной в Переднюю Азию, Центральную Азию, Северный Кавказ, Поволжье, Иран. Здесь был большой массив тюркского населения, как уже подчеркивалось, окончательно еще не сформировавшегося в единый народ. В этом регионе были сильны также и религиозные догматы, особенно среди мусульманского населения, и здесь была бакинская нефть. Именно поэтому данное пространство и стало одним из важнейших театров борьбы как великих держав, так и различных идеологий.

В начале XX века в Баку, как уже отмечалось выше, возникли и политические течения и силы, которые пропагандировали выход из состава России вкупе с идеями пантюркизма и панисламизма. Первой такой организацией стала образованная в конце 1905 года партия тюркских социал-фредералистов «Гейрат», ратующей за отделение Кавказа от России с предоставлением автономии мусульманскому населению ${ }^{98}$.

Однако наиболее известной партией пантюркистского толка, конечно же была, партия «Мусават», основанная в 1911 году. Одним из первых политических актов, предпринятых партией, был выпуск прокламации - воззвания в 1912

\footnotetext{
98 Об этой партии см. Казиев М.А. Из истории революционной борьбы бакинского пролетариата (1905-1910гг.). Баку, 1956, стр. 98; Самедов В.Ю. Распространение марксизма-ленинизма в Азербайджане. Ч. II, Баку, 1966, стр. 61; Сеидзаде Д.Б. Из истории азербайджанской буржуазии в начале XX века. Баку, 1978, стр. 71-72.
} 
г., в связи с первой Балканской войной и напечатанной в Стамбуле в журнале "Сабил-ур-Решад». В воззвании указывалось на то, что до сих пор мусульманский мир, сердцем которого являлся Османский халифат, подвергался страшным гонениям и унижениям со стороны европейских государств, надеявшихся, что, не выдержав этого натиска, он лишится былого могущества. «Единоверцы! - говорилось далее, - Наша единственная надежда и дорога к спасению лежит в независимости и прогрессе Турции. Если мы и дальше будем равнодушно взирать на ее беды, то сами окажемся в плену у врага... Организатором всех этих дел является враг ислама и всего человечества, известный как «мировой жандарм» северный медведь - деспотичное русское государство» ${ }^{99}$. Весьма активизировалась работа турецких эмиссаров и мусаватистов в 1913г. после падения Адрианополя, грозящего поражению Турции в войне. Тогда на Кавказ из Стамбула было командировано 60 офицеров, местных уроженцев, с целью проведения широкой пропагандистской работы для подготовки в случае необходимости восстания мусульман против России ${ }^{100}$. Как утверждал лидер партии Мамед Эмин Расулзаде: «Образование единого туранского государства наподобие германского - было идеалом, с достижением которого «тюркская раса, была бы в апогее своей славы, и затаенные в ней потенциальные силы, развернувшись, дали бы свету совершенно новые, культурные ценности» ${ }^{101}$.

\footnotetext{
99 Багирова И.С. Политические партии и организации Азербайджана в начале ХХ века 1900-1917. Баку, 1997, стр. 101.

100 Багирова И.С. Указ. соч., стр. 172.

${ }^{101}$ Мухаммед Амин Расулзаде. Пантуранизм и проблема Кавказа. Доклад, прочитанный в марте 1930 года в Париже перед аудиторией, состоящей из представителей кавказской, украинской и туркестанской эмиграции. Turan
} 
Однако не только вышеуказанные татарские или мусульманские политические силы видели свое будущее в союзе с Османской Турцией. Отдать обширные территории Кавказа и других регионов Турции были готовы и другие силы. Так, образованная еще в начале XX века в Тифлисе грузинская группа "Сакартвело" вошла в контакт по определению царской полиции с так называемым «панисламистским комитетом» в целях отделения Кавказа от России, которое должно было произойти на следующих условиях: Тифлисская и Кутаисская губерния, Батумская область и Северный Кавказ составляют будущую автономную Грузию, а Эриванская, Бакинская и Елисаветпольская губернии с Закаспийской областью - войти в состав Турции и Персии ${ }^{102}$.

Совершенно очевидно, что будучи главной преградой на пути пантюркистов, Российская империя предпринимала важные шаги в борьбе с этими угрозами. Особенно уязвимы в данном контексте представали окраины империи, у населения которых, по определению ряда исследователей, зачастую наблюдается так называемый феномен двойственной лояльности, проявляющийся в тенденции перехода на сторону побеждающей силы ${ }^{103}$. В немалой степени этому способствовало и весьма сильные позиции исламского духовенства в обществе. Так, в Кубинском уезде насчитывалось 451 семейство духовных лиц, в среднем от 1 до 2 семейств на каждую деревню, или же по 1 семейству на каждые 30 кре-

Today, торкский мир сегодня,

http://www.turantoday.com/2011/03/rasulzadeh-panturanizm-kaukas.html, 11 декабря 2011.

102 Багирова И.С. Указ. соч., стр. 86.

103 Подробнее о данном феномене см. Lattimore Owen, The New Political Geography of Inner Asia, The Royal Geographical Society Journal, Vol. 119, March 1953, pp. $165-167$. 
стьянских семей ${ }^{104}$. В регионе это духовенство составляло особый класс, а их дети почти всегда поступая в духовное звание ${ }^{105}$, поддерживали самовоспроизводство этой прослойки, которая, естественно, была под особым вниманием центральных властей империи.

Однако, такая двойственность могла возникнуть не только на переферии, но и в самом, казалось бы, центре. Такое в истории России было, причем не один раз. Одним из наиболее опасных примеров можно назвать активное участие российских мусульман в восстании Пугачева (17731775гг.) в борьбе с центральной властью, что в СанктПетербурге считали результатом политики Османской империи ${ }^{106}$. В начале XX века в пропаганде панисламизма и пантюркизма в Закавказье, Османской империи активно помогала Германия посредством своей разведки, а также дипломатических миссий, местных немецких колонистов, немецких компаний и даже туристических организаций, издательских домов и лютеранского духовенства ${ }^{107}$.

Антироссийские чувства мусульманам прививали и в других западных странах, особенно в разного рода образовательных учреждениях. Как писал один из крупнейших представителей пантюркизма Исмаил-бей Гаспринский: «Мусульмане, получающие образование на Западе или слушающие лекции у профессоров, приглашенных оттуда,

${ }^{104}$ Сумбатзаде А.С. Кубинское восстание 1837г. Баку, 1961, стр. 38.

105 Акты, собранные Кавказской археографической комиссией. Том VII, Тифлис, 1878, документ N373, стр. 432.

106 Fisher Alan W., Enlightened Despotism and Islam Under Catherine II, Slavic Review, Vol. 27, N4, December 1968, p. 550.

107 Саркисян Е. Экспансионистская политика Османской империи в Закавказье накануне и в годы первой мировой войны. Ереван, 1962, стр. 106, 118119. 
или изучающие науки по переводам книг того же Запада, конечно, имеют крайне смутное и неправильное представление о России и о русском народе. Арабы, турки, персы, не говоря уже о мусульманах Индии, зная Россию по английским, немецким и фрранцузским источникам и не имея ни одного самостоятельного сочинения о соседней великой северной стране, всегда легко поддавались на убеждения западных друзей и охотно надевали на свои носы их очки» ${ }^{108}$. Пантюркисты утверждали, что «ненависть - полезный источник силы для нации, а месть - двигатель этой силы... Великие дела творит только ненавидящая и мстящая нация» $^{109}$.

Всплески панисламистских страстей также происходило после потерей Османской империей таких территорий, как Тунис и Египет, захваченных соответственно Францией и Британией, а также колонизации Индии британцами ${ }^{110}$. Естественно, что поддержка пантюркизма великими европейскими державами преследовала также и цель направить недовольство мусульман и османов и их политики на русских.

Естественно, что Российская империя предпринимала ответные шаги по борьбе с панисламизмом и пантюркизмом. Одним из механизмов, была политико-мировоззренческая основа государственного строительства в Российской империи. Интересно, но Российская империя считала себя

108 Исмаил-бей Гаспринский. Русско-восточное соглашение, Арабески истории. Кн. I, Москва, 1994, стр. 374-375.

109 Караев С.Н. Большевики Азербайджана в борьбе за интернациональное сплочение рабочего класса, автореферат докторской диссертации. Баку, 1974 , стр. 61.

${ }^{110}$ Keddie Nikki R., The Pan-Islamic Appeal: Afghani and Abdülhamid, Middle Eastern Studies, Vol. 3, N1, 1966, p. 48. 
не только страной, покорившей мусульманские, в том числе и тюркские, государства (ханства), но и их наследницей, а в каком-то смысле, даже правопреемницей этих государств. Не случайно, например, что на гербе Российской империи в качестве первичных гербов были и символы Казанского, Астраханского и Сибирского ханств ${ }^{111}$. Более того, отношение русских к мусульманам и тюркам было достаточно терпимое и даже теплое. Вот как об этом в свое время писал тот же Исмаил-бей Гаспринский: “Для мусульманских народов русская культура более близка, чем западная. Экономическая и индустриальная сила русского народа несравненно менее опасна, чем западная, менее коварна, более терпима. Мусульманин и русский могут еще вместе или рядом пахать, сеять, растить скот, промышлять и торговать; их умения не слишком разнятся... Культурная, так сказать, стихийная близость народов Востока с русским народом видна из того, что нигде сын Востока так легко не обживается, как в России» ${ }^{112}$.

Но этим меры, предпринимаемые Российской империей, не ограничивались. Параллельно проводился и весьма широкий комплекс классических мер. Одним из важнейших направлений была, как уже отмечалось, соответствующая административно-территориальная политика, а также фрормирование новых этносов, в частности, кавказских татар.

Весьма эфффективным методом было и использование противоречий вышеуказанных оппозиционных к режиму политических сил как для борьбы с этими силами, так и для

111 Подробнее о российской имперской геральдике см. Дворянские роды Российской империи. Санкт-Петербург, 1993; Фон Винклер П.П. Гербы городов Российской империи. Санкт-Петербург, 1900.

112 Исмаил-бей Гаспринский. Указ. соч., стр. 376. 
недопущения их консолидации против центральных властей. Естественными антиподами здесь выступали пантюркисты, панисламисты и большевики. Как писала в одном из своих номеров большевистская газета «Новая жизнь» за 1905 год: «Панисламизм должен быть обезврежен - это сделает социал-демократия, обнажив сущность панисламизма перед кавказским пролетариатом, вообще, и татарским, в частности ${ }^{113}$.

Центральные власти умело использовали и межнациональные противоречия и проблемы, в результате чего зачастую имели место весьма жестокие конфоликты между теми или иными народами. Среди наиболее кровавых были армяно-татарские столкновения 1905-1906гг., имевшие место в Баку, Елизаветполе и других городах ${ }^{114}$. По некоторым данным, в ходе столкновений 1905 года были разрушены порядка 300 армянских и татарских поселений и погибло, по разным оценкам, от 3 до 10 тысяч человек ${ }^{115}$.

Эти события привели к анархии в нефтяной промышленности, приостановили на длительное время проходку скважин, они заполняли водой буровые и сокращали добычу нефти и данный кризис продолжался до конца 1906 года, что отразилось на производстве нефти - 4 старых нефтеносных района Баку потеряли 231,4 миллиона пудов сырья ${ }^{116}$.

\footnotetext{
${ }_{113}$ Национализм как один из источников хулиганства. Новая жизнь, N 11, 12 (25) ноября 1905.

114 О погромах в Елизиаветполе см., к примеру, Алибегов И. Елисаветпольские кровавые дни пред судом общества. Тифлис, 1906.

${ }^{115}$ Swietochowski T., Russia and Azerbaijan: A Borderland in Transition, Columbia University Press, 1995, p. 40.

116 Азербайджанская нефть в политике мира. Вторая книга. Баку, 1997, стр. 62.
} 
Но в организации этой бойни обвиняли не только царские власти, но и вмешательство других стран - геополитических соперников Российской империи. Так, русский писатель и публицист А.В. Амфитеатров (1862-1938гг.) указывал на конкретные фракты «мусульманского заговора» сторонников турецкого султана Абдул-Хамида ${ }^{117}$.

Однако кроме вовлечения царских властей или других стран, столкновения были и результатом определенных внутренних противоречий. Так, ряд исследователей подчеркивали достаточно неистовые антиармянские чувства у татарской интеллигенции, которыми и умело пользовались центральные власти ${ }^{118}$.

Весьма интересный анализ этих противоречий дал Иосиф Сталин в своей известной работе «Марксизм и национальный вопрос», написанной в 1913 году. Сталин писал следующее: "Стесненная со всех сторон буржуазия угнетенной нации естественно приходит в движение. Она апеллирует к «родным низам» и начинает кричать об «отечестве», выдавая свое собственное дело за дело общенародное. Она вербует себе армию из "соотечественников» в интересах... «родины». И «низы» не всегда остаются безучастными к призывам, собираясь вокруг ее знамени: репрессии сверху задевают и их, вызывая в них недовольство... Если, например, в Грузии нет сколько-нибудь серьезного антирусского национализма, то это прежде всего потому, что там нет русских помещиков или русской крупной буржуазии, которые могли бы дать пищу для такого национализма в массах. В Грузии есть антиармянский национализм, но это потому, что там есть еще армянская крупная буржуазия, которая, поби-

\footnotetext{
117 Амфитеатров А.В Армянский вопрос. Санкт-Петербург, 1906, стр. 53. 118 Villari Luigi, Fire and Sword in the Caucasus, London, 1906, p. 170. 
вая мелкую, еще не окрепшую грузинскую буржуазию, толкает последнюю к антиармянскому национализму»" ${ }^{119}$.

Тем не менее, до поры до времени империи удавалось контролировать ситуацию в Закавказье, нейтрализовать угрозы и проблемы. Ситуацию кардинально и бесповоротно изменила Первая мировая война.

Падение Российской империи было наиболее благоприятным временем для осуществления этих геополитических планов ${ }^{120}$. Для юридического обоснования своих притязаний официальные лица Оттоманской империи и создали второй Азербайджан в Закавказье. Логика была весьма простой и гениальной с геополитической точки зрения. В случае существования двух образований с одинаковым названием они, естественно, должны были объединиться.

Эта политика вызвала отрицательную реакцию соседних стран, в частности Ирана. В докладе, адресованном рейхсканцлеру Германии, глава делегации Германии на Кавказе, в частности, отмечает: «В Персии вызвал недовольство тот фракт, что турки назвали «Азербайджаном» закавказскую республику, ближе всех расположенную к востоку, для обоснования территориальных претензий к персам. Недовольство усугубляет также то обстоятельство, что персы не являются друзьями татар ${ }^{121}$. Более того, правители Оттоманской империи стремились к образованию общей

119 Сталин И.В. Марксизм и национально-колониальный вопрос. Сборник
статей и речей. Москва, 1937, стр. 12.
120 Pomiankowski J., Der Zusammenbruch des Ottomanischen Reiches.
Erinnerungen an die Türkei aus der Zeit des Weltkrieges, Zurich-Leipzig-Wien,
1928, S. 29-30; Hostler Ch.W., Turkism and the Soviets. The Turks of the World
and their Political Objectives, London, 1957, p. 146ff. 121 Центральный регистр: 1918-А-48749, серийный номер посольства/консульства: J. Nr. D. 1629. 
границы с новым суррогатным государством, и Азербайджан стал предъявлять территориальные претензии на исторические территории сопредельных народов - грузин, дагестанцев, армян и т.д. В случае с армянами, новообразованный Азербайджан попытался захватить Карабах, Зангезур, Севанский регион, Араратскую долину, в том числе, Ереван, что и явилось причиной возникновения карабахского конфликта.

Однако, в ходе Первой Мировой войны турки потерпели поражение, да и к тому же независимый Азербайджан просуществовал очень короткий срок и постоянно был ареной борьбы великих держав. Нового народа здесь создано не было. Но была заложен фундамент нового государственного образования, создание такого образования кардинально изменило геополитику и историю как Закавказья, так и всего Ближнего Востока.

Тюркизация и азербайджанизация тюркоязычного и мусульманского населения нового Азербайджана в советском государстве

После советизации Закавказья геополитическая важность данной республики была для советского государства весьма заметной. Одним из ключевых компонентов этого была бакинская нефть. В 1940 году, например, Азербайджан давал 71,4\% всей нефти, добываемой в СССР 122 . Haceление города продолжало расти. Так, если в 1913 году население Баку составляло 389,6 тыс. человек, то в 1933 году оно возросло до 709,5 тыс. человек и столица Азербайджа-

122 Народное хозяйство СССР. Статистический сборник. Москва, 1956, стр. 69. 
на по численности населения заняла третье место в СССР после Москвы и Ленинграда ${ }^{123}$.

Но кроме этого Азербайджанский ССР превратилась в фрорпост распространения большевизма на Ближнем Востоке ${ }^{124}$. Азербайджан был первой и до 1930-ых годов единственной мусульманской республикой Советского государства (центральноазитские республики были автономиями с составе Советской России - Д.Б.), и Кремль использовал этот фракт для снижения авторитета имперских держав, в частности, Великобритании и Франции в мусульманских колониях этих стран от Среднего Востока до Индии. Именно по этой причине советские власти, по мере возможностей, удовлетворили территориальные претензии Азербайджана, передав ему из исторических армянских территорий весь Карабах (Арцах) и Нахичеван, более половины Зангезура. В состав Советского Азербайджана были также переданы ряд грузинских и дагестанских земель. Этот шаг представлял геополитическую целесообразность для большевиков, так как в мусульманском мире Азербайджан стал олицетворением коммунистической революции. Помимо этого, Азербайджан был удобным рычагом давления на Иран в вопросе Иранского Азербайджана.

Однако на первом этапе советская власть придерживалась весьма интересной политики. В Азербайджане, например, всячески поддерживалось этническое разнообразие

\footnotetext{
123 Очерки истории Коммунистической партии Азербайджана. Баку, 1963, стр. 497.

124 Ленин В.И. Полное собрание сочинений, том 51, Москва, 1970, стр. 227; Первый съезд народов Востока. Стенографические отчеты. Петроград, 1920, стр. 8; Партийный архив Азербайджанского филиала Института марксизмаленинизма (ПААФ ИМЛ), ф.7, оп.1, ед.хр. 5, л.3.
} 
и национальное самосознание ${ }^{125}$. Вдобавок к этому, советская власть отказалась от этнонима «кавказские татары» и вместо этого ввела в обиход новую национальную идентичность для тюрков Закавказья, назвав их попросту тюрками Советского Азербайджана. По всей видимости такой переход был сделан в контексте распространения большевизма и коммунизма среди тюркоязычного массива Турции и Ирана. Тем не менее, дальнейшие фундаментальные геополитические трансформации на мировой арене породили новые вызовы и необходимость изменения тактики и стратегии национального строительства в Азербайджане.

С приходом А. Гитлера к власти в Германии в 1933 году стало очевидно, что новая мировая война неизбежна. В данной ситуации Азербайджан, из наступательного компонента советской геополитики, стал одним из наиболее уязвимых. Основная причина этого заключалась именно в этнической специфике данного государственного образования. Азербайджан был единственной республикой бывшего СССР, название которого не было производным от названия какого-либо народа или этногруппы. В отличие от других советскихх республик, название которых было производным от государствообразующего народа, например, Армения, Грузия, Россия, и т.д., Азербайджан населяли этногруппы тюркского, кавказского, иранского происхождения, а также армяне, грузины, русские и евреи. Примерно 52

125 Собрание узаконений и распоряжений рабоче-крестьянского правительства Азербайданской ССР. Баку, N 1, 1920, стр. 5; Там же, N2, 1921, стр. 2425; Резолюции 2-го съезда АКП(б), Баку, 1920, стр. 6; Орджоникидзе Г. Статьи и речи. Москва, 1956, том 1, стр. 296; Центральный государственный архив Октябрьской революции (ЦГАОР) СССР, ф.1318, оп.1. д.657, л.29-30; ПААФ ИМЛ, ф.14, оп.1, ед.хр.8, л.65; ЦГАОР Азерб. ССР, ф.57, оп.1. д. 44 , л.3. 
процентов населения составляли тюркоязычные народы, объединенные под названием «тюрки Советского Азербайджана». Примечательно, что, согласно данным переписи 1920-х годов, тюркское население Персии, проживающее в Азербайджане, упоминается как отдельная этническая группа - тюркское население Персии ${ }^{126}$.

Этническая группа «азербайджанские тюрки» представляла значительную опасность, так как могла с легкостью пойти на союз с Турцией, как это произошло во время Первой мировой войны. Так, 24 ноября 1941 года сотрудники посольства Германии в Турции направили послание в Берлин, где сообщалось о работе, проведенной с азербайджанскими турками в целях освобождения Кавказа от Советской власти, при этом Турция претендовала на статус фактического хозяина этого региона ${ }^{127}$. Турция планировала вступить в войну на стороне Германии и ждала подходящего для этого момента. К таковым можно отнести, например, Сталинградскую битву и в случае победы немцев турецкие войска должны были открыть новый фронт в Закавказье ${ }^{128}$. Но даже не вступив офрициально в войну, Турция практически до самого ее конца снабжала Германию стратегически

\footnotetext{
126 Большая советская энциклопедия. Том 1, раздел «Азерб. ССР». Москва, 1929, стр. 641.

127 «Руководитель азербайджанских тюрков об освобождении Кавказа», перевод с немецкого. Копия. Германское посольство. Анкара, документ №A6032, 24 ноября 1941 года, информация взята из вебсайта Наша победа, http://9may.ru/unsecret/m10011709.

128 Миллер А.Ф. Очерки новейшей истории Турции. Москва, 1948; Лавров Н. М. Турция в 1939-1951гг. Лекции, прочитанные в ВПШ при ЦК ВКП(б), Москва, 1952; Еремеев Д.Е. Турция в годы Второй мировой и «холодной» войн (1939-1990), Москва, 2005.
} 
важнейшими видами сырья, в частности, хромом ${ }^{129}$. Турецкая Республика объявила войну Германии лишь 23 фревраля 1945 года ${ }^{130}$.

Учитывая традиционно тесные связи между Германией и Турцией, а также события, произошедшие на Кавказе в 1918 году, Советский Союз принял решение сорормировать новую нацию. Реанимация "кавказских татар» была уже невозможна. Поэтому было принято создать «азербайджанскую» нацию, причем "сверху» и ускоренными темпами. Под новым названием «азербайджанцы» были объединены различные мусульманские народы и этногруппы с целью создания исторической, культурной и политической платформы для недопущения идентификации тюрок Восточного Закавказья с турками, проживающими в Турции. Именно так в 1936 году в мире появилась новая нация - азербайджанцы ${ }^{131}$.

Базой консолидации мусульманских народов Азербайджанской Советской Социалистической Республики в единый азербайджанский народ должна была стать территориально-административная принадлежность. Люди различных национальностей должны были идентиорицировать себя как азербайджанцы, т.е. жители Азербайджана. После того, как общая самоидентификация была бы привита, она со временем должна была эволюционировать в национальное самосознание и национальную идентичность (нацию). Аналогичным образом развивалсь национальная

\footnotetext{
${ }^{129}$ Vander Lippe J.M., The Politics of Turkish Democracy: Ismet Inönü and the Formation of the Multy-Party System, 1938-1950, New York, 2005, p. 96.

${ }^{130}$ Akşin Sina, Turkey's Declaration of War on Germany at the end of World War II, The Turkish Yearbook of International Relations, Vol. XXXIII, 2002.

131 Алекперов А. Исследования по археологии и этнографии Азербайджана. Баку, 1960, стр. 71.
} 
идентичностью, например, американцев. Азербайджан был единственной республикой СССР, в которой это можно было сделать, так как название государства, как уже было указано выше, не было производным от основного народа, населявшего его территорию. Таким образом частью новой азербайджанской общности становились потомки древних кавказских албанцев - лезгины, носители иранской культуры - талыши, таты, курды и другие народности, горские народы, а также тюркский этнос.

Необходимость легитимизовать существование новой нации потребовала внесения коррективов и в историю. Малейшее проявление интереса к истории или культуре этнического меньшинства, а также любой намек на проявление неазербайджанского самосознания подавлялось со всей суровостью. Один Азербайджан был не в состоянии самостоятельно осуществить эту нелегкую задачу и успех данного проекта всецело зависел от центра, что стало одной из его главных геополитических задач в Закавказье.

Создав новую азербайджанскую нацию, Советский Союз действительно решил ряд геополитических вопросов. Прежде всего, была сорормирована новая нация, которая не идентифицировала себя с турками Турции. Кроме этого, эта новая нация полностью зависела от СССР, так как, будучи искусственно образованной и весьма слабой, она могла сохранить целостность лишь при поддержке Центра, центральных властей СССР.

Тем не менее, возникли и новые проблемы. Так, несмотря на использование колоссального государственного ресурса, эволюционирование общей самоидентификации в национальное самосознание и национальную идентичность в Азербайджане произошло несколько иначе, чем планиро- 
валось. Самоидетнификация в качестве азербайджанцев, а затем ее трансорормация в национальное самосознание и национальную идентичность достаточно успешно прошла среди тюркоязычного населения республики. Но этот процесс среди других народов происходил медленее. Поэтому процесс национальной консолидации в Советском Азербайджане начал приобретать совершенно иное направление. Тюркская элита, успешно пройдя цепь самоидентификация - самосознание - национальная идентичность, начала фактически навязывать азербайджанскую идентичность другим мусульманским народам республики и их элитам, для которых азербайджанская общность находилась в основном все еще на стадии самоидентификации. В результате мусульманские нацменьшинства Азербайджана стали воспринимать азербайджанскую общность как попытку другого народа навязать им свою национальную идентичность. Поэтому азербайджанская общность не стала консолидирующим элементом для всех мусульманских народов республики.

Кроме того, начались и весьма опасные идеологические проблемы. Важнейшим из них стала постепенная подмена интернационализма на национализм в Азербайджане. В Советском Азербайджане, многонациональном государстве, своеобразном микро-Советском Союзе на Кавказе, бок о бок проживали представители различных этногрупп. Однако искусственное формирование новой нации сверху в геополитических целях привело к постепенному торжеству национализма, сначала на негласном уровне, а затем, особенно по мере ослабления советской власти, уже и совершенно открыто. А это было очень опасно, особенно в таком стратегически важном регионе, как Закавказье. 
Данный процесс имел объективные предпосылки. Дрейфр тюркской части элиты Азербайджана в сторону национализма и навязывания азербайджанской идентичности другим народам, был продиктован рядом факторов. Здесь, конечно, был элемент своеобразного симбиоза соблазна и страха. Соблазн заключался в том, что создавалась своего рода «мини-имперская» нация и «мини-империя» и необходимо было полноценно использовать предоставившейся возможности для этого в максимально короткий срок. Страх заключался в наличие объективных и серьезных препятствий на этом пути.

Важнейшим из них был имено Нагорный Карабах (Арцах). Если мусульманские народы Азербайджана, у которых много общего в традициях, культуре, религии и менталитете, могли консолидироваться в единую азербайджанскую общность, то армяне, также как и русские, евреи и другие не исповедующие ислам народы республики, сохранили свою национальную идентичность. Но в отличие от других немусульманских народов, армяне Карабаха имели не только уходящую вглубь веков историю государственности, но и свою государственность, пусть даже в фрорме автономной области. Ассимилировать армянский Карабах было попросту невозможо. Можно было попытаться изменить этнонациональный состав этой автономной области, добиться превращения армян в меньшинство. Кстати, именно эта политика с успехом была проведена в другом автономном образовании Советского Азербайджана - Нахичеванской Автономной Советской Социалистической Республике, где за несколько десятилетий практически не осталось армянского населения. Но с Карабахом этого не получилось по целому ряду причин, важнейшей из которых были такие 
черты армян Карабаха, как жизнестойкость, мощнейшая привязанность к родной земле, бунтарский нрав и т.д. Фактически, если бы Нагорный Карабах не был бы насильно включен в состав Азербайджана, то процесс консолидации мусульманских народов этой республики в единую азербайджанскую общность прошел бы более успешно. В этой ситуации азербайджанская (тюркская) элита, видя в Карабахе главную угрозу своей государственности и национальной консолидации, выбрала давление в качестве основы политики в данном регионе и по отношению к нему.

Все это стало также своеобразным вызовом и процессу самоопределения азербайджанского народа, одновременно более туже завяз узел азербайджано-армянских отношений ${ }^{132}$. Азербайджанцы стали рассматривать Карабах уже в качестве своей этнической территории, а не как административную единицу другого народа. Отныне разногласия между двумя нациями - азербайджанцами и карабахскими армянами перешли на новый, межнациональный уровень.

Ситуация усугубляется и тем, что процесс формирования новой, азербайджанской нации до сих пор не завершен. Да, некоторые этнические группы, например иранские таты, практически ассимилированы в единую азербайджанскую нацию. В Азербайджане исчезли также курды, ряд дагестанских народов. Тем не менее, некоторые народы до сих пор сумели сохранить в той или иной степени свою национальную идентичность. К ним принадлежат кавказоязычные лезгины и аварцы, компактно проживающие на севере современной Азербайджанской Республики, на границе с Дагестаном, а также ираноязычные талыши, ареал

132 Бабаян Д. Нагорно-карабахский конфликт и самоопределение азербайджанского народа. Центральная Азия и Кавказ, N 5, 2003, стр. 84-94. 
которых находится юге Азербайджана, на границе с ИраHOM.

Ввиду этого Азербайджан живет под постоянной угрозой самоопределения этих наций, что может привести даже к распаду данного государства. Такие прецеденты в истории современного Азербайджана были. Так, в XX веке талыши два раза провозглашали государственность. 15 мая 1919 года была провозглашена Муганская Советская Республика, просуществовавшая около трех месяцев ${ }^{133}$. Около трех месяцев просуществовала и провозглашенная в конце июня 1993 года Талыш-Муганская Автономная Республика ${ }^{134}$. 28 сентября 1991 года решением Общенационального съезда лезгинского народа, прошедшего в селе Касумкенд Дагестана, была принята декларация о восстановлении государственности лезгинского народа и о создании Республики Лезгистан по обе стороны реки Самур ${ }^{135}$.

Несмотря на то, что талышская государственность была уничтожена азербайджанскими властями, а решение лезгин так и осталось на бумаге, эти и другие народы не отка-

133 О данном государственном образовании см. Искендеров М.С. Из истории борьбы Коммунистической партии Азербайджана за победу Советской власти. Баку, 1958, стр. 389; История гражданской войны в СССР, Москва, 1959, том 4, стр. 324; Кадишев А.Б. Интервенция и гражданская война в Закавказье. Москва, 1960, стр. 186-187; Азербайджанская Демократическая Республика (1918-1920). Армия: Документы и материалы. Баку, 1998, стр. 8.

134 О данном государственном образовании см. Шнирельман В.А. Войны памяти: мифы, идентичность и политика в Закавказье. Москва, 2003, стр. 118; Жирохов М. Меч и огонь Карабаха. Хроника незнаменитой войны. 1988-1994, Москва, 2012, стр. 24; «В Азербайджане глава Талышского культурного центра осужден на 10 лет тюрьмы». Кавказский Узел, http://www.kavkaz-uzel.eu/articles/138341_, 24 июня 2008.

135 Абдурагимов Г. Кавказская Албания - Лезгистан: история и современность. Махачкала, 1995, стр. 409. 
зались от своей борьбы. Так, талыши периодически обращаются к различным странам и международному сообществу в целом, обращая внимание авторитетных структур на постоянного давление со стороны властей Азербайджана. К примеру, в 2008 году они обратились к представителям европейских стран ${ }^{136}$, в 2009 году - к международному сообществу ${ }^{137}$. С подобными обращениями выступали также другие нацменьшинства. В 2008 году аварцы обратились к президенту Дагестана с просьбой защитить от проводимой бакинскими властями политики насильственной азербайджанизации ${ }^{138}$.

Нередко происходят также конфликты и стычки между представителями нацменьшинств и властями страны, в том числе и на региональном уровне. Так, в марте 2017 года в Кабалинском районе Азербайджанской Республики фрермеры лезгинской национальности организовали протесты в всязи с изгнанием лезгинских фермеров с ряда сельхозугодий и произволом властей ${ }^{139}$.

Зачастую конфрликт между нацменьшинствами и центральными властями Азербайджана переходит в соседние

136 «Европа, ты должна услышать наш правый голос!» Толыш Пресс, http://tolishpress.org/news/364.html

137 «Заявление Талышского национального движения, адресованное всем международным организациям, всем правозащитным организациям и правозащитникам мира» Толыш Пресс, http://tolishpress.org/news/671.html, 15 апреля 2009.

138 «Аварцы Азербайджана просят президента Дагестана защитить их от азербайджанизации». Кавказский узел,http://www.kavkazuzel.ru/newstext/news/id/1223420.html, 18 июня 2008.

139 Саркаров Амиль. «Убирайтесь куда хотите». Лезгин продолжают выдавливать из северных районов Азербайджана». РИА «Дербент», http://riaderbent.ru/ubirajtes-kuda-khotite-lezgin-prodolzhayut-vydavlivat-izsevernykh-rajonov-azerbajdzhana.html, 7 марта 2017. 
государства, в частности, в российский Дагестан. Так, в конце июня 2013 года в Дербенте прошли массовые акции протеста в связи с тем, что властями было принято решение о присвоении имени Гейдара Алиева одной из центральных улиц города. Организаторами акций были Федеральная лезгинская национально-культурная автономия, общественная организация "Садвал», "Общество Храх-Уба», которые считают, что последствия передачи Азербайджану двух лезгинских сел, водосбора реки Самур и фрактического отчуждения 2,5 тысяч га лезгинских пастбищных земель в рамках процесса демаркации российско-азербайджанской границы приводят к ущемлению прав этнических лезгин ${ }^{140}$.

Имеется и достаточно сильное недовольство этнических меньшинств Азербайджана относительно действий властей данной страны по отправке представителей нацменьшинств в зону азербайджано-карабахского конфрликта. Несколько лет назад целый ряд общественных организаций и лидеров коренных народов Азербайджана обратились с воззванием к проживающим в республике соотечественникам, где указали на то, что в течении десятилетий руководство Азербайджана заставляет коренные народы воевать с армянами Арцаха - Карабаха, назвав это самой большой несправедливостью, в которой коренные народы Азербайджанской Республики невольно принимают участие ${ }^{141}$.

Ситуация усугубляется и тем, что политике отуречивания Азербайджана и его населения, как одной из современ-

\footnotetext{
140 «Акция "Дербент - южный форпост России". Твитт-трансляция. Следующий митинг намечен на сентябрь». Кавказский узел. http://www.kavkazuzel.ru/articles/226344/, 29 июня 2013.

${ }^{141}$ См. Война с армянами в Карабахе - не наша война: обращение, ИА Regnum, http://www.regnum.ru/news/polit/1478044.html, 10 декабря 2011.
} 
ных составляющих идеологии пантюркизма, активно способствует и Турция. Так, азербайджанские и турецкие лидеры, начиная с распада СССР, активно пропагандируют лозунг «одна нация - два государства» ${ }^{142}$. Такая позиция и внешнеполитический курс также направлен на подрыв существующего геополитического баланса не только в Закавказье, но и для всего Ближнего, Среднего Востока, Центральной Азии и вплоть до Китая.

Таким образом, нарушенный в Азербайджане естественный цикл формирования азербайджанской нации и становления национальной идентичности, является одним из самых главных объективных препятствий не только, как уже упоминалось выше, на пути урегулирования нагорнокарабахского конфрликта, но и нормализации армяноазербайджанских отношений и отношений азербайджанцев (тюрков) с другими народами самой Азербайжанской Республики. Здесь действительно исключена всякая возможность недискриминационного отношения титульной нации т.е. азербайджанцев к другим народам, в том числе и к армянам.

Гармоничное сосуществование двух народов в рамках общего государства невозможно также и в условиях отсутствия какой-либо общей идеологии. В советское время

\footnotetext{
142 Речь Президента Азербайджанской Республики Гейдара Алиева на торжественной церемонии вручения Президенту Турецкой Республики Сулейману Демирелю ордена Истиглал - 18 октября 1999 года. «Бакинский рабочий», 20 октября 1999; Президент Ильхам Алиев: Азербайджанская и турецкая диаспоры будут действовать как единый орган. Тренд, http://ru.trend.az/news/top/895653.html, 9 марта 2007; «Президент Ильхам Алиев: Гейдар Алиев имеет большие заслуги в развитии турецкоазербайджанских отношений. Тренд, http://www.trend.az/azerbaijan/politics/2375028.html, 17 марта 2015.
} 
такой идеологией был коммунизм, но и он не смог создать соответствующих условий. Этого не сумеет сделать и демократия, так как ввиду незавершенности процесса фрормирования азербайджанской нации, демократия там, в Азербайджане, в принципе невозможна. Если там будет установлена демократия, то Баку должен будет признать право Нагорного Карабаха на самоопределение. Но в таком случае и другие народы этой республики, например, лезгины и талышы, могут потребовать независимости. А это уже представляет непосредственную опасность самому существованию Азербайджана как независимого государства.

\section{Заключение}

Вышеуказанные исторические, этнические и политические фракторы сорормировали новый менталитет политической элиты Азербайджана. Единственным способом сохранения государственной целостности для нее является подавление любого национального движения в среде нацменьшинств. В подобных государствах конфликт и конфронтация заменяет компромисс и сотрудничество. Азербайджан воспринимает Нагорный Карабах как главную угрозу самому фракту существования своего государства. Азербайджан не может признать независимость Нагорного Карабаха, так как в этом случае другие народности последуют примеру последнего. Он также не предоставит автономию Карабаху, даже несмотря на то, что она абсолютно неприемлема для Арцаха. Для Азербайджана автономия представляет даже большую опасность, чем независимость, так как другие этногруппы могут также потребовать автономию, что чревато не только возможным переходом к независимости, но и улетучиванию самого понятия единой и консолидированной 
азербайджанской нации, и возможно, пробуждением других ассимилированных нетюркских народов. Таким образом, для Азербайджана имеются лишь два варианта решения азербайджано-карабахского конфрликта. Первое, Карабах без армян, и второе - замораживание разрешения конфрликта невозможностью претворения в жизнь первого сценария.

Даже если конфрликт будет урегулирован и Азербайджанская Республика вынуждена будет признать независимость Нагорного Карабаха, то это государство вряд ли откажется от антиармянской политики, так как продолжение антиармянской политики среди прочего дает возможность Баку показать другим нацменьшинствам, что он ни в коей мере не смирится с потерей той или иной территории и те, в свою очередь, лишний раз подумают прежде чем решат встать на путь сецессии. Таким образом, в Азербайджане создалась ситуация, при которой самоопределение одного народа воспринимается как угроза самоопределению других народов $^{143}$.

143 Бабаян Д. Ключи карабахского конфликта - в руках Азербайджана. https://regnum.ru/news/307529.html, ИА Регнум, 13 августа 2004. 


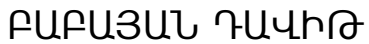

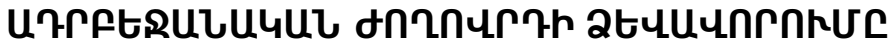

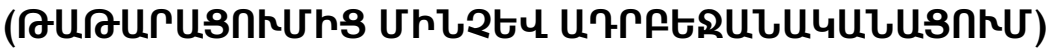

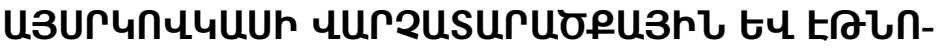

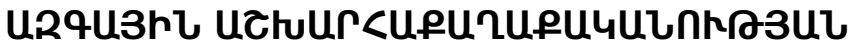 cUuUSteUSกhU XIX-XX १?.}

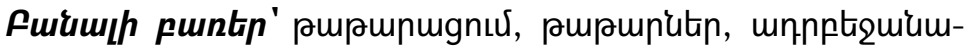

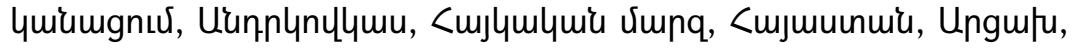

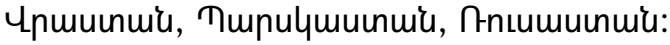

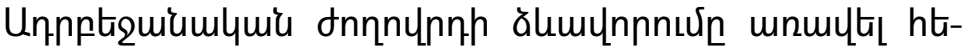

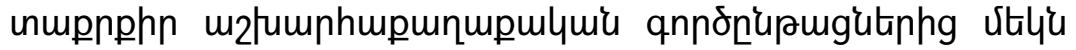

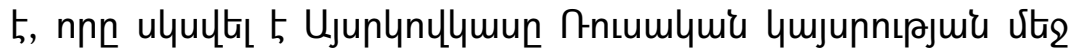

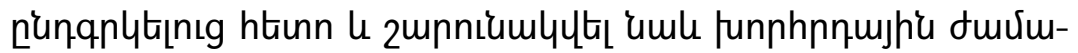

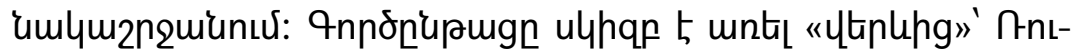

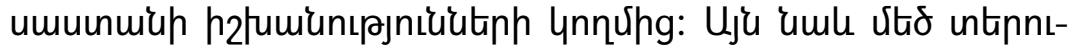

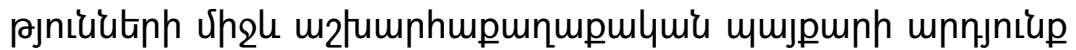

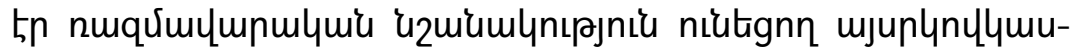

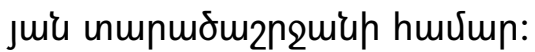

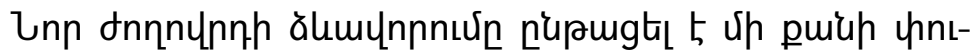

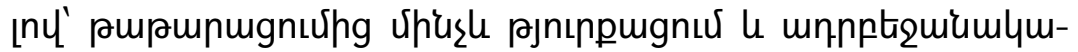

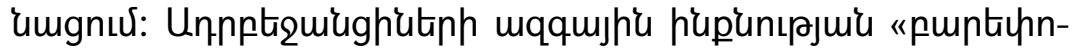

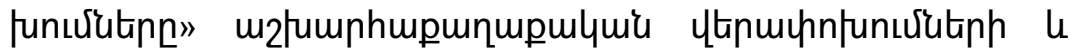

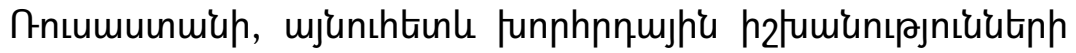

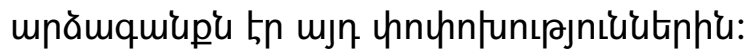

